\title{
THE LAPLAND GREENSTONE BELT: STRATIGRAPHIC AND DEPOSITIONAL FEATURES IN NORTHERN FINLAND
}

\author{
MATTI SAVERIKKO
}

\begin{abstract}
SAVERIKKO, MATTI, 1987: The Lapland greenstone belt: Stratigraphic and depositional features in northern Finland. Bull. Geol. Soc. Finland 59, Part 2, 129-154.

The Lapland greenstone belt formed in a continental environment, as a result of rifting of the 3.1-3.0 Ga Samian craton. The basin subsided to a depth of five kilometres between 3.0-2.5 Ga and contains a sequence which is subdivided into Lower, Middle and Upper Lapponian groups, with the Middle Lapponian metasediments separating the Lower Lapponian Salla-Jauratsi and Upper Lapponian Kittilä greenstone successions. After a folding episode the Lapponian supergroup was covered with the Kumpu conglomerate-metasandstone--slate suite, occurring as Karelian, i.e. Sariolan-Jatulian, deposits. A few erosional remnants are capped with Svecofennian rocks $1.9 \mathrm{Ga}$ old.

The Lower Lapponian consists of basal arkose, the Möykkelmä greenstones, a cratonic quartzite-carbonate-schist suite and the Salla greenstone complex(es) preserving evidence of a lava plateau. The Salla bimodal metavolcanic rocks and the Middle Lapponian metasediments, which, at their thickest, constitute the Oraniemi arkose - slate - quartzite association (incl. redbeds), evidently indicate cratonic rifting that terminated with the growth of isolated lava fields of Fe-rich tholeiitic basalt. In the Upper Lapponian, euxinic-exhalative metasediments underlie the Sattasvaara, Sotkaselkä and Kummitsoiva komatiite complexes and the Kittilä greenstones, which are present as complicated but distinct eruption centres and contain a varying amount of ejecta and volcaniclastic greywacke-slate intercalations. The komatiite-dominant succession evidently represent mantle-activated rifting and the linear mantle upwelling.

The Lapland greenstone belt and adjacent granulitic belt appear to constitute a paired metamorphic terrain, where the overthrusting of the granulites is explained by mutual motions of the distinct cratonic megablocks.
\end{abstract}

Key words: greenstone belts, metamorphic rocks, lithostratigraphy, chronostratigraphy, evolution, Archean, Proterozoic, Lapland, Finland.

Matti Saverikko: Department of Geology, University of Helsinki, P.O. Box 115, SF-0017I Helsinki, Finland.

\section{Introduction}

The Finnish Precambrian can be broadly subdivided into the Archaean basement, Svecokarelian fold belt, rapakivi granites and Jotnian sedimentary rocks (Fig. 1). The Archaean basement is dominated by cataclastic gneissose granitoids of quartz-dioritic, granodioritic and granitic composition (Simonen 1980) but also contains supracrustal greenstone belts (Gaál et al. 1978); the granulitic arc in the north, regarded by Meriläinen (1976) as Archaean, is considered by Barbey et al. (1984) a Karelian high-grade metamorphic terrain. 

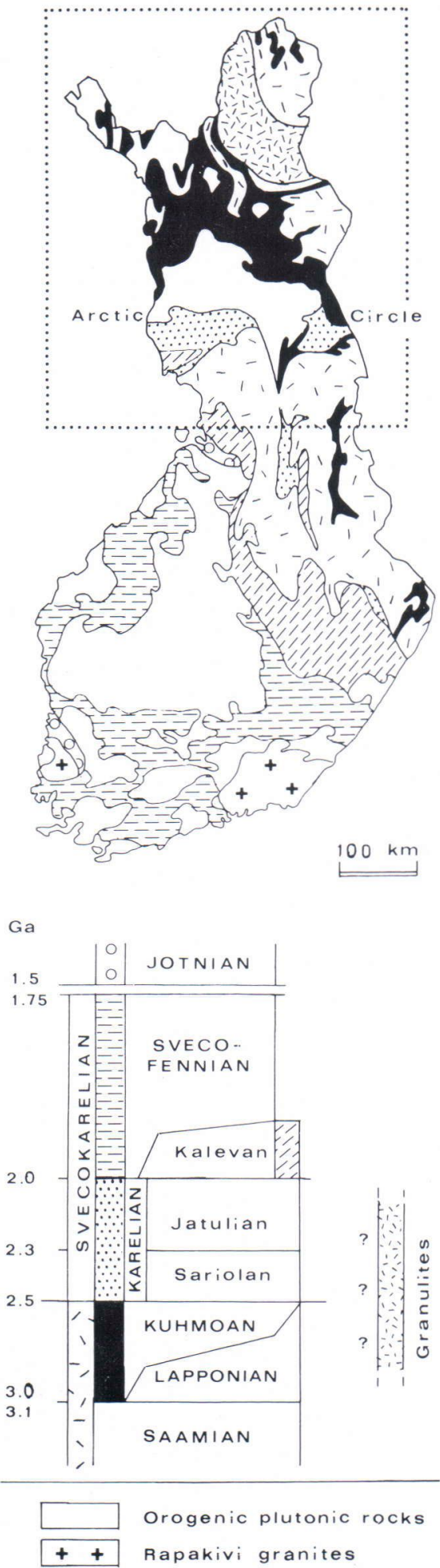

The gneissose granitoids commonly give ages of 2.8-2.6 Ga, even though many rocks are 3.2-2.8 Ga old (Simonen 1980; Kröner et al. 1981; Luukkonen and Lukkarinen 1986; Paavola 1986; Huhma 1987) pointing to a Saamian origin (Silvennoinen 1985). On the other hand, granitoids of $2.8-2.4 \mathrm{Ga}$ age also occur (Martin 1987) and the basement has been subjected to polyphase deformation and metamorphism (e.g. Kröner et al. 1981; Luukkonen 1985; Paavola 1986) resulting in a very complicated structural history. It is referred to generally as the PreSvecokarelian granite-gneiss complex, with an older Saamian body of obscure extent.

The Kuhmo-Suomussalmi greenstone belt in the east forms distinct synforms between granitoid diapirs (Gaál et al. 1978) occupied by the Kuhmoan supergroup (Simonen 1971; Luukkonen and Lukkarinen 1986). Deposition occurred at $3.0-2.5 \mathrm{Ga}$ (Piirainen 1985) within continental to oceanic rift environments (Martin et al. 1984).

In the north, metavolcanic rocks accumulated in the Kittilä and Salla-Jauratsi greenstone areas (Fig. 2), constituting part of the Lapponian supergroup (Sederholm 1932; Silvennoinen et al. 1980) deposited on the disintegrated granitegneiss complex (Mikkola 1941) and underwent high-grade metamorphism in the Tuntsa-Savukoski ultrametamorphic terrain (Gaál et al. 1978). This Lapland greenstone belt is disrupted by granites whose geochemistry indicates substantial recycling of Archaean crustal material (Lauerma 1982; Huhma 1986). The Lapponian deposition at 3.1-2.6 Ga (Silvennoinen et al. 1980), and perhaps continuing into the Early Proterozoic (Silvennoinen 1985), took place in a cratonic rift (Saverikko 1985; Saverikko et al. 1985; Silvennoinen 1985; Manninen and Pihlaja 1988) or geosynclinal basin environment (Mäkelä 1968; Paakkola 1971; Piirainen 1975).

Fig. 1. Stratigraphic outline and Precambrian subprovinces in Finland, compiled after Meriläinen (1980), Silvennoinen et al. (1980), Simonen (1980) and Gaál and Gorbatschev (1987). The map area in Figure 2 is marked with a dotted line. 

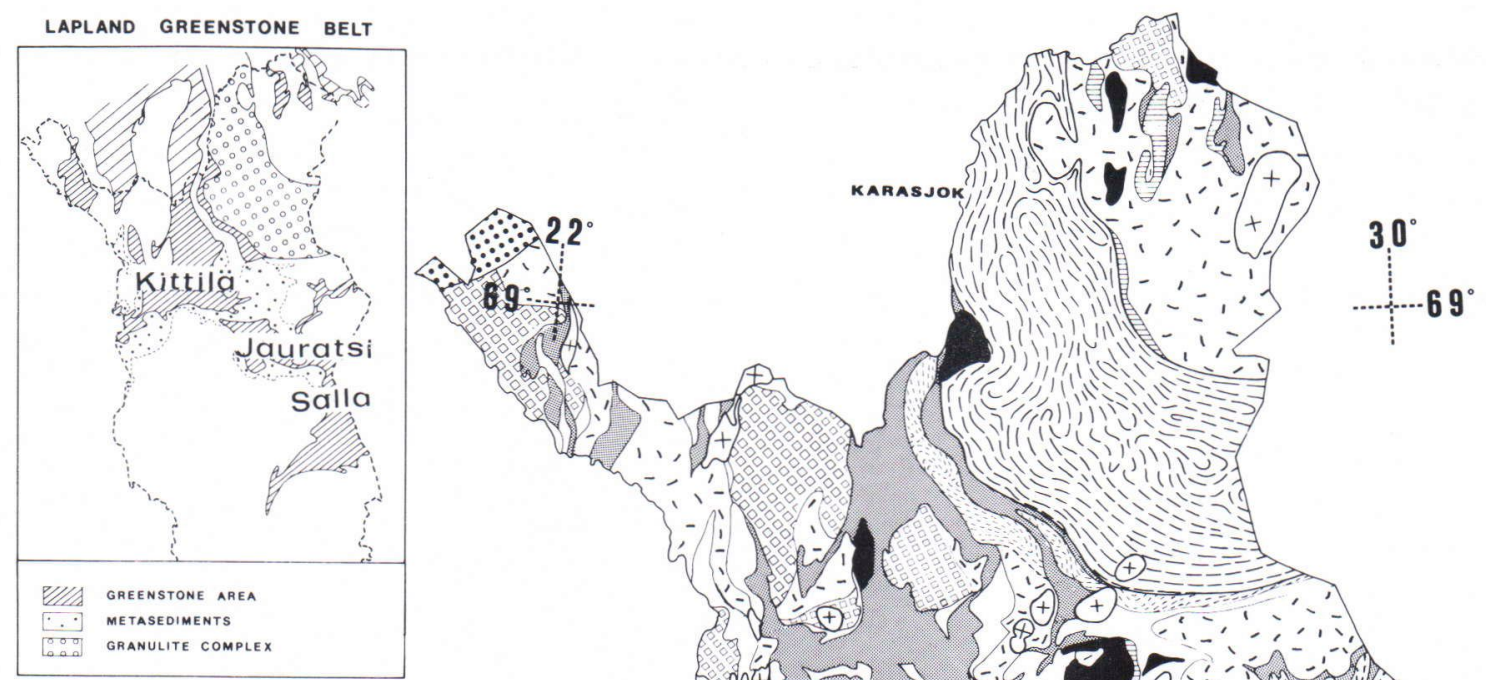

LITHOLOGIC MAP
of

North Finland

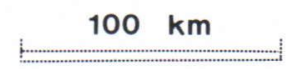

\section{CALEDONIAN ROCKS}

GRAPHITIC and/Or CARBONATIC METASEDIMENTS

METAVOLCANICS (greenstones, komatiitic rocks etc.) QUARTZITIC ROCK, ए” MICA SCHIST

MIGMATITES (mica gneiss, arkose gneiss, amphibolite) GRANITIC GNEISSES ,

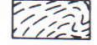
GRANULITES

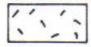

$++$ GRANITE ,

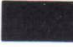

GABBROID

GRANODIORITE, QUARTZ DIORITE and MONZONITE

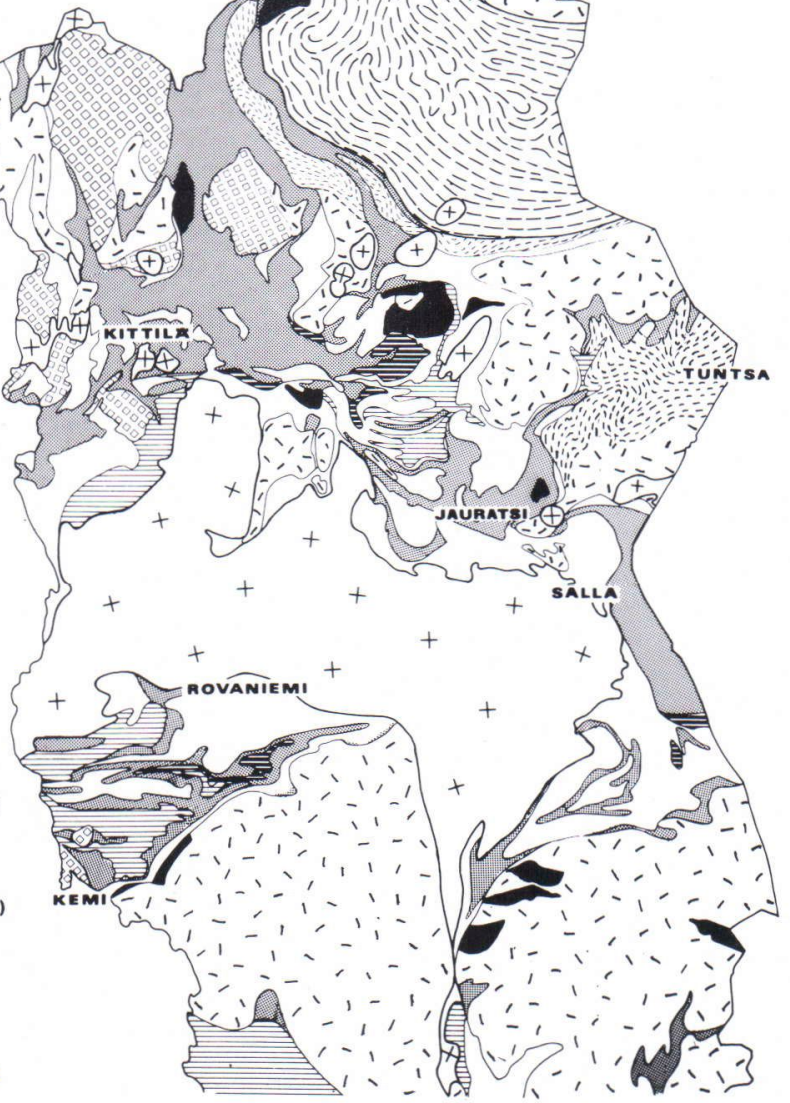

Fig. 2. Geological sketch map of the Lapland greenstone belt (incl. the Tuntsa-Savukoski ultrametamorphic terrain) and the granulite complex. Minor continuations of the Petsamo/Pechenga greenstone belt (U.S.S.R.) extend into northernmost Finland. The map is modified after Meriläinen (1976), Silvennoinen et al. (1980) and Simonen (1980).

The Karelian supergroup is composed of the Sariolan and Jatulian deposits (Gaál and Gorbatschev 1987). The Sariolan coarse-clastic rocks are of limited occurrence and record stable platformal, riftal or glacial palaeoenvironments (Pekkarinen 1979; Gaál 1980; Marmo and Ojakangas 1984; Laajoki 1986a; Marmo et al. 1986), whereas the Jatulian quartzites were deposited in a shallow epicontinental sea (Ojakangas 1965) and are in turn overlain by the Marine-Jatulian dolomite-black-slate association; the Karelian sequence includes also mafic metavolcanic rocks, (Meriläinen 1980; Simonen 1980).

The platformal strata are overlapped by the 
Svecofennian geosynclinal sequence (Simonen 1980) including the Kalevan slate-greywacke association (Gaál and Gorbatschev 1987). These latter formed in a continental shelf setting so that the terrigenous sediments derived from the Sariolan-Jatulian deposits and the Archaean basement (Huhma 1987); arkosic conglomerates and other phenoclastics at the base indicate marginal rifting and base-of-slope environment (Honkamo 1985; Perttunen 1985; Ward 1987; references in Luukkonen and Lukkarinen 1986). The Svecofennian domain proper consists of newly mantle-derived material with only a minor component from older continental crust (Huhma 1986). The crustal segment displays direct evidence of volcanic arcs, subduction and collision (references in Gaál 1986; Huhma 1986) and the bulk of the epiclastics in the thick volcanicsedimentary sequence was eroded from the recently formed crust (Huhma 1986, 1987).

The Svecokarelian fold belt was intruded by anorogenic rapakivi granites recording the onset of continental rifting (Nurmi and Haapala 1986), produced some fault-bounded troughs (Kahma 1978) in which the Jotnian arkose-shale redbed association was deposited (Simonen and Kouvo 1955).

\section{Lithologic characteristics}

The Lapponian supergroup underlies erosional remnants of Karelian deposits and consists greenstones and two metasedimentary assemblages (Hackman 1927), of which, according to Mikkola (1941), the younger Oraniemi arkoseschist—quartzite suite should be linked rather with the Kumpu(tunturi) conglomerate-metasandstone-slate suite of Karelian origin. The remainder of the Lapponian is lithostratigraphically comparable to the Kuhmoan supergroup (Mikkola 1941). However, the Oraniemi rock suite has also been regarded as part of the Lapponian sequence (Silvennoinen 1985). These discrepancies in stratigraphic interpretation (cf. Hackman

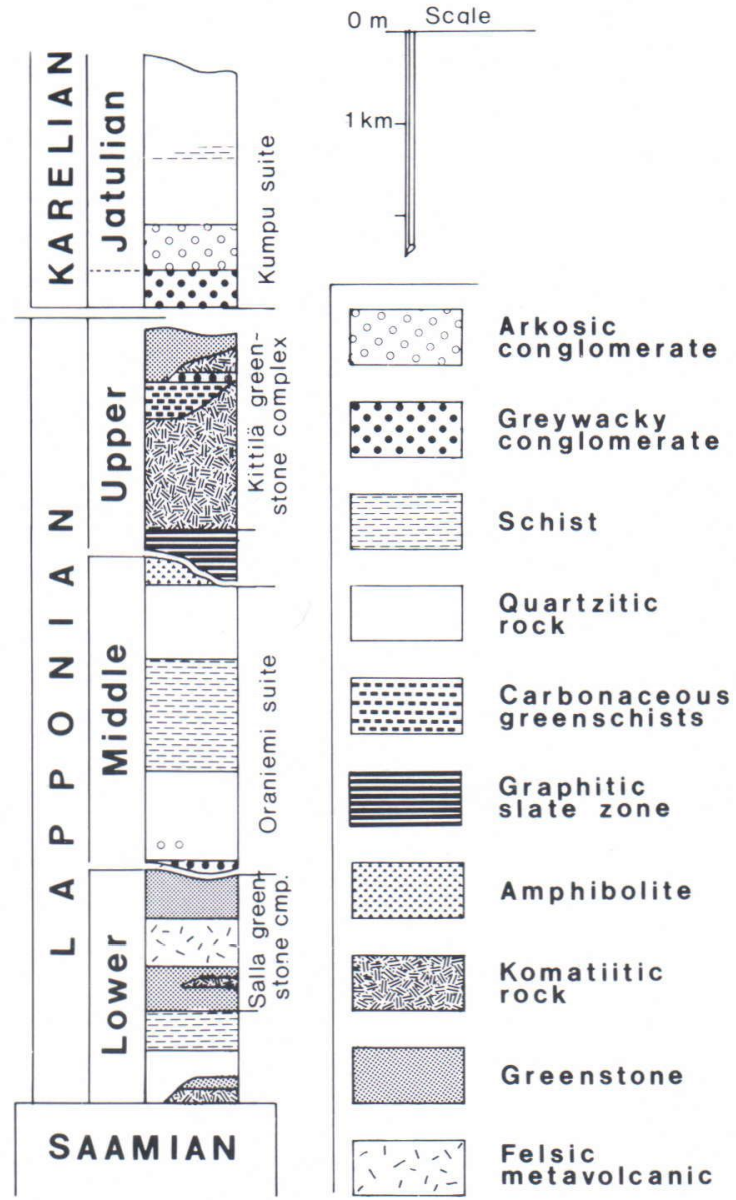

Fig. 3. Composite stratotype from the key area is based on the stratigraphic columns presented in Figure 5 (see p. 141). The Salla greenstone complex is doubtless much thicker than in measured cross-sections because of its enormous extent. The Lapponian sequence is considerably thinner, and lacking in some, particularly Middle Lapponian units, at the northeast margin of the greenstone belt (see Mattila 1974; Isomaa 1978; Saverikko 1978, 1983).

1927; Mikkola 1941; Silvennoinen et al. 1980) may be resolved by invoking, instead of a bipartite subdivision, Lower, Middle and Upper Lapponian groups (Fig. 3).

The key area (Fig. 4) includes the northern part of the Salla-Jauratsi greenstone area and the southeastern corner of the Kittilä greenstone area. The following lithologic and petrographic 


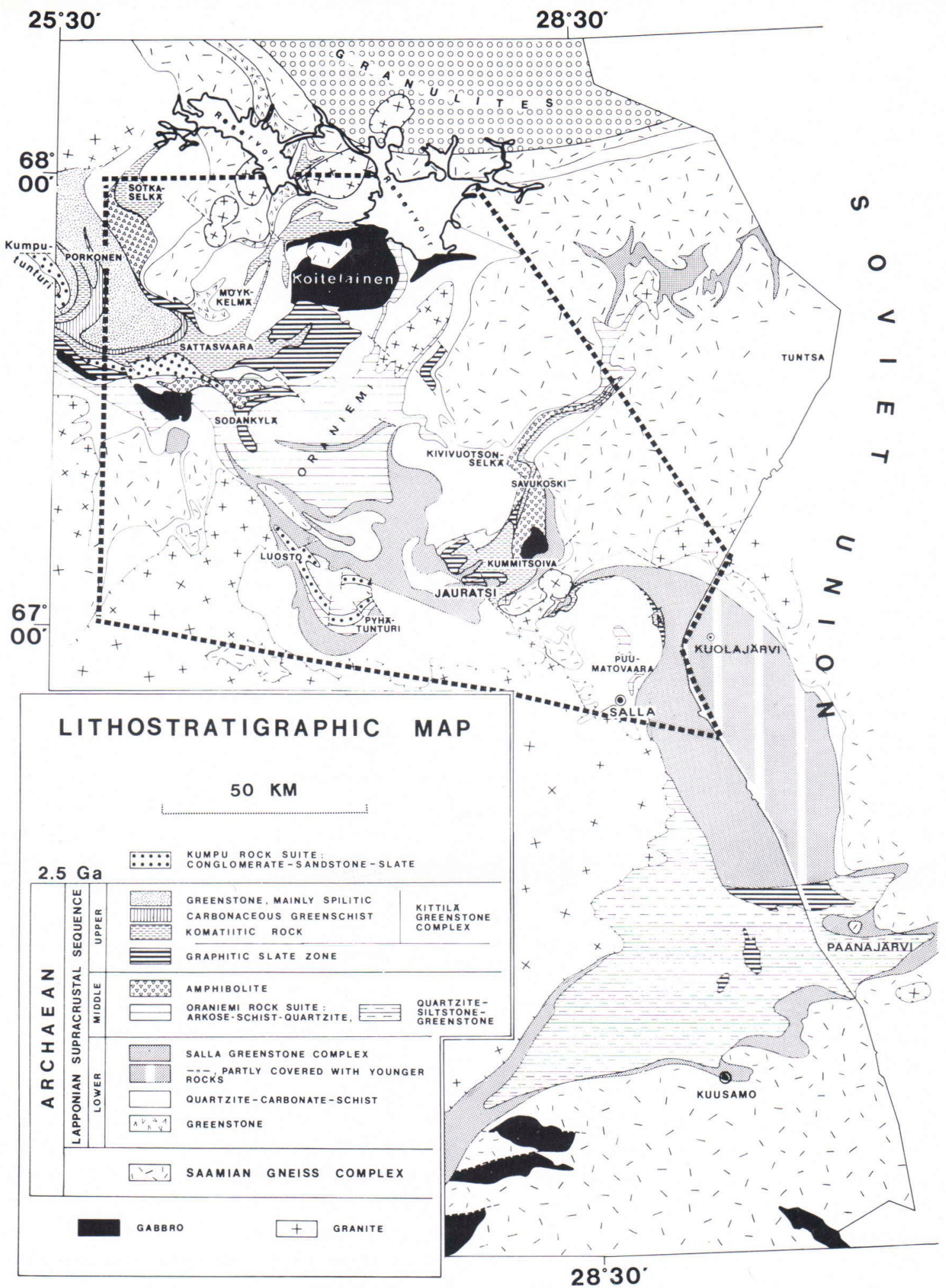

Fig. 4. Lithostratigraphic map of central and eastern Finnish Lapland. The key area is marked with a dashed line; geology has been revised after Haimi (1977), Kallio et al. (1980), Saverikko (1978, 1985, 1988a), Saverikko and Manninen (1981) and Manninen and Pihlaja (1988). 
descriptions are compiled from various publications, theses and research reports.

\section{Saamian gneiss complex}

The Saamian gneiss complex is composed of gneissose granitoids that form a weakly deformed to veined and intensely folded rock assemblage, including granoblastic or cataclastic rocks of granitic, granodioritic, trondhjemitic, tonalitic and quartz-dioritic composition. The granitoids also contain concordant enclaves and palaeosomes of amphibolite, mica gneiss, hornblende gneiss or conglomeratic arkose gneiss particularly prominent to the east of the village of Savukoski. Granitic streaks and feldspar metacrysts show incipient migmatization in both the orthogneisses and paragneisses. The gneiss complex was weathered prior to Lapponian deposition and palaeoresidue is widespread.

\section{Lower Lapponian group}

Basal arkose or quartzite usually lie directly on weathered basement, since the lowermost, greenstone unit beneath them is rarely exposed. The upper part of the group consists of the extensive Salla greenstones.

The Möykkelmä greenstones are poorly known, but in the north there are two exposures that are largely tuffaceous amphibole-mica rock with gneiss fragments towards the base. When appreciable amounts of bombs and lapilli are present, the lapilli tuff passes to amphibole rock with agglomeratic or blocky tuff texture. Pyroclastics and infrequent lavas of komatiitic composition ( $\mathrm{MgO} 13-21 \mathrm{wt} \%$ ) envelop and underlie tholeiitic greenstones of andesitic to basaltic composition (Räsänen et al. 1986), now present as coarsely vesicular amphibole-plagioclase rocks. The volcanic pile is $250 \mathrm{~m}$ thick at the type locality at Möykkelmä, from which similar rocks can be traced northwards (Manninen and Pihlaja 1988), while a spinifex-textured komatiitic rock at Kivivuotsonselkä (Räsänen 1983, 1984) may also be included in this assemblage.

Basal arkose, up to $20 \mathrm{~m}$ thick, appears to cover the basement except in the east, where an arkose quartzite and quartz-pebbly conglomerate are separated by a distinct contact from the basement. The basal arkose passes into Lower Lapponian quartzite.

The Lower Lapponian quartzite-schist sheet begins with a quartzite blanket, $0.1-0.3 \mathrm{~km}$ thick at the margin overlain by and interdigitating with a somewhat thicker schist unit at the depocentre. The metasediments include also intercalate with uralitized mafic lithologies in the east and southeast.

The feldspathic quartzite is thinly stratified and contains quartz-arenitic deposits and interlaminae, and sporadic quartz-pebbly accumulations. The fine-grained quartzite is usually granoblastic but the matrix in blastoclastic rocks is feldspathic with minor carbonate and mica. The rock grades into quartz-feldspathic schist or sericitic schist that is fuchsitic in places. Peculiar to the quartzite are quartzose laminae, and disseminations and bands of calc-silicate minerals. The calc-silicate rock forms several thin and extensive interlayers and dolomite is present in scattered lenses or ribbons. Small-scale cross-beds, slump folds, ripple marks and mud cracks are found in the least foliated rocks.

The schist consists mainly of biotite and muscovite, and bedding is seen as thin quartzfeldspathic or calc-silicatic bands. Pelitic $\left(\mathrm{Al}_{2} \mathrm{O}_{3}\right.$ $<36.6$ wt \%, $\mathrm{Fe}_{2} \mathrm{O}_{3}$ tot $<21.3$ wt \%) interbeds occur within the semipelitic schists as bands alternately rich or poor in aluminium-silicate porphyroblasts (Niemelä 1976). Garnet and calciumsilicate minerals together with dominating biotite are the most typical minerals, although cordierite is a distinctive minor constituent.

The Salla greenstone complex, $1-1.5 \mathrm{~km}$ in measured thicknesses, consists virtually entirely of mafic greenstones: phaneritic rocks are in excess of evidently effusive greenstones including aphanitic lavas and minor pyroclastics. Felsic 
rocks make up an extensive interlayer, up to 1 $\mathrm{km}$ thick, and a few graphitic or dolomitic beds (h. $1-10 \mathrm{~m}$ ) and some small dolomite inclusions are contained in both felsic and mafic rocks. Several gabbros, hornblendites and serpentinites are also present in the complex.

The mafic greenstones of aphanitic texture are lavas rich in amygdules concentrated into peculiar flow structures, and pyroclastics in which tuffs grade into slate and rare quartzitic or dolomitic beds. The phaneritic rocks are massive to slightly oriented both in the differentiated lava flows and in sills or dykes intruding the other greenstones. The main minerals in the lavas and pyroclastics are hornblende-actinolite, albiteandesine and epidote. Biotite can also be a major mineral, and sphene is a minor component. Where the texture is not granoblastic, the phaneritic rock is blastophitic, the aphanitic rock is microporphyritic, and the tuff is blastoclastic to nematoblastic. While some lava flows have tremolitic or talcose basal cumulates, not all the ultramafics are differentiates, since an amphibolechlorite rock of komatiitic composition, for instance, is associated with tuffs (Manninen 1981), and a lithic-vitric coarse tuff is mineralogically of komatiitic affinity; these rocks underlie the felsic rocks.

The felsic rocks are lavas of intermediate to acidic composition but also acidic tuffaceous rocks: calc-alkaline dacites and rhyolites and tholeiitic andesites are recognized from scant geochemical data (Manninen 1981).

The intermediate lavas are phaneritic and massive or aphanitic and amygdaloidal in texture. The cumulophyric or porphyritic lavas are sometimes weakly propylitized but the mineral assemblage is mainly albite-oligoclase, quartz, hornblende and biotite. Magnetite is a common minor constituent and sulphides occur in bands or disseminations.

The acidic rocks are largely tuffs, present as laminated or banded rocks, and minor lavas that are massive rocks with or without small amygdules and plagioclase phenocrysts; pillow lavas are quite the exception. The major minerals in both rocks are quartz, albite-oligoclase, sericite and biotite. The tuffs contain plagioclase also as coarse-grained crystal ejecta and show chemical evidence of possible terrigenous material (Manninen 1981). Magnetite that is partly martinitized has been enriched into several deposits in the lavas, including ferruginous chert. Minor sulphides occur in rare fragmentary lavas.

\section{Middle Lapponian group}

The Middle Lapponian group is composed of the Oraniemi arkose-slate-quartzite association (Saverikko 1988a) with amphibolites at the top. The Lower-Middle Lapponian marker is a volcaniclastic greywacke-slate blanket $(50 \mathrm{~m}$ thick), varying from phenoclast-supported conglomerate to pebbly rock (Haimi 1977; Kröner et al. 1981; Saverikko 1988a). Comparable rocks (Silvennoinen 1972; Rastas 1980; Veki 1985; Virransalo 1985) are encountered at an analogous stratigraphic level outside the key area.

The marker is characterized by the amphibolic matrix in which some hornblende-actinolite grains of good roundness exhibit authigenic overgrowth; epidote and quartz occur as well. The volcaniclastic debris changes to clayey, and the rock devoid of the phenoclasts is usually thinly stratified. The highly rounded pebbles and cobbles are granitoid, cordierite-staurolite schist, hornblende gneiss, vein quartz, quartzite, carbonate rock, felsic rock, and greenstone mineralogically similar to the matrix. The matrix is tholeiitic basalt in chemical composition and is therefore considered tuffaceous in origin (Kröner et al. 1981).

The Orakoski arkose is stratified in a homogeneous deposit (h. $0.9-1.2 \mathrm{~km}$ ) of arkose quartzite except for redbeds at the base and a few arkosic conglomerate lenses, known as the Huhtakumpu conglomerate, in the lower part of the deposit. The arkose quartzite is clearly clastic and the arenaceous detritus derives from cataclastic granitoids: the clasts are polygonal quartz, 
mortar-structured K-feldspar and plagioclase (An 10-35), and minor rock particles. The mainly arenitic mixture of medium, coarse and very coarse sands together with sericitic matrix form beds, 5-25 $\mathrm{cm}$ thick, which are distinguished by greenish micaceous or grey metalliferous interfaces. Current bedding is ubiquitous in the form of channel-fill cross-beds with channellag gravel or festoon cross-beds of large scale. The Huhtakumpu conglomerate contains highly rounded pebbles and cobbles of vein quartz, granitoids and rarely slate in a rhythmically upward-coarsening pile interbedded by the arkose quartzite.

The metapelite sheet $(1-1.7 \mathrm{~km}$ thick) comprises slate with andalusite, staurolite and kyanite, grading through schist into sillimanite gneiss. The rock is enriched in aluminium $\left(\mathrm{Al}_{2} \mathrm{O}_{3} \quad 16.9-30.1\right.$ wt $\left.\%\right)$ and iron $\left(\mathrm{Fe}_{2} \mathrm{O}_{3}{ }^{\text {tot }}\right.$ 6.1-12.2 wt \%) (Rask 1978, Leppänen 1985), accounting for the characteristic abundance of aluminium-silicate porphyroblasts and magnetite grains throughout the rock. Chloritoid and plagioclase porphyroblasts are also typical but they are not invariably present. The negligible quantities of calcium and manganese are insufficient for the formation of garnet (Rask 1978). Uniform stratification occurs as laminae and thin planar beds usually exhibiting graded bedding.

The Sodankylä quartzite formation is sericite quartzite about $1 \mathrm{~km}$ thick but the marginal zones are more arkosic, overlying a thin calc-silicate rock and a greenstone unit of limited extent.

The arkose quartzite is coarse to fine-grained arenite or wacke of arkosic composition, and the detritus with a higher degree of roundness is mineralogically similar to that in the Orakoski arkose, but numerous argillic clasts have squashed into a quartz-feldspar-sericite pseudomatrix. Heavy minerals are tourmaline, apatite, zircon and epidote, exhibiting secondary overgrowth or high roundness. Composite bedsets succeed in rhythmic pattern and are comprised of laminated to ripple-bedded fine sand or silt and parallel-bedded to cross-bedded sand, which both are variously convoluted. Highly rounded isolated quartz pebbles occur sporadically.

The sericite quartzite consists of laminae alternately rich in quartz or sericite and of sericitic flasers associated with quartzose lenticular beds. The matrix is fuchsitic in places and although monomictic detritus dominates, feldspar clasts occur near the arkose quartzite: the well rounded sand grains floating in the sericitic matrix are distinctive to the Sodankylä quartzite (Hackman 1927), and in the fines, plagioclase (An 10-15) is in excess of K-feldspar, although the contents of both are small. Mud cracks with or without haematite accretions occur, too.

The Oraniemi assemblage has erosional remnants at Luosto, Jauratsi and Puu-Matovaara. The exposure at Luosto includes the marker, the terminus of the Orakoski arkose and haematitebearing metasediments relative to the Sodankylä quartzite (see Haimi 1977). At Jauratsi the arkosic conglomerate contains pebbles and cobbles of granitoid, felsic rock, schist, greenstone, calc-silicate rock and fuchsitic quartzite within the arkosic to greywacky matrix that is faintly pigmented with haematite. The deposit at PuuMatovaara is sericite quartzite rich in carbonate but it includes minor arkosic or quartzose interbeds. The quartzite is striated with calc-silicate minerals and contains an intraformational conglomerate towards the base.

Amphibolite from isolated lava fields is mostly structureless, albeit flow structures and flowtop breccias are present, and lava pillows and infrequent amygdules are found, too. The granonematoblastic rock consists of hornblende and oligoclase-andesine with epidote and biotite. Quartz and sphene can also be major constituents and uralitized phenocrysts imply cumulative pyroxene. The top of the flow pile is generally banded, containing several dark horizons with disseminated graphite and interlayers of graphitic slate and jasper. Garnet is a typical mineral of the banded amphibolites. The massive rocks are Fe-rich tholeiitic basalts in composition (Sarapää 1980; Manninen 1981) but the banded rocks 
are enriched in aluminium and depleted in magnesium (Sarapää 1980): the banded rocks can be considered to derive from detritus rather than from primary ejecta, that should explain the enrichment in quartz and feldspar.

\section{Upper Lapponian group}

Graphitic and jaspery interbeds within the banded amphibolites (Kallio et al. 1980; Saverikko and Manninen 1981; Kerkkonen 1982) are accepted here as marking the Middle-Upper Lapponian transition. Similar banded amphibolites (Latvalahti 1973; Meriläinen 1976; Hiltunen 1982) in comparable lithologic surroundings also occur outside the key area. Because the amphibolites are absent over large areas, the boundary stratotype is in practice the lower contact of the graphitic slate zone.

The graphitic slate zone consists typically of slates with variable graphite content. The graphite-poor slates sometimes contain andalusite and staurolite, but sulphide disseminations and laminae, garnet and amphibole needles in or outside radial aggregates are most typical to the slate zone. The interbedded members are greywackes, calc-silicate rocks; dolomites and mafic volcaniclastics along with scattered greenstones. Serpentinitic or peridotitic rocks of komatiitic origin (Saverikko 1985) and strongly albitized or carbonatized felsic rocks that were originally autobrecciated or massive lavas and pyroclastics, in association with adinoles also occur (Pulkkinen et al. 1983). A few polymictic conglomerates are found in greywacky or haematitic slates but individual pebbles are scattered throughout many metasediments. The banded iron formations with sulphide slates at Jauratsi (Rieck et al. 1967) are also included in the slate zone, which commonly contains chert and jasper in streaks and nodules.

Kittilä greenstone supercomplex is composed largely of the Sattasvaara komatiite complex (Saverikko 1985, Manninen and Pihlaja 1988), which is komatiitic basalt ( $\mathrm{MgO} 9-18$ wt $\%)$ in the lower and middle parts but pyroxene perido- titic komatiite ( $\mathrm{MgO} 18-30$ wt \%) and greenstone in the upper part, also including a few flows and necks of peridotitic komatiite $(\mathrm{MgO}>30$ wt $\%$ ); the greenstones prevail in the west (Paakkola 1971). The upper part is separated by carbonaceous greenschists with volcaniclastic conglomerates at the top, and it is comparable with the isolated komatiite complexes at Kummitsoiva and Sotkaselkä (Kallio et al. 1980; Saverikko 1983). The komatiite complexes are about $2 \mathrm{~km}$ thick.

The komatiitic basalt is amphibole rock usually with plagioclase as disseminations or laminae. The nematoblastic to microporphyritic rock consists of actinolite, saussuritized plagioclase and minor epidote or zoisite together with chlorite; the microlithic groundmass surrounds uralitic or chloritic pseudomorphs and ocelli or varioles. The phaneritic to aphanitic rocks are pillowed to massive lavas usually with amygdaloidal or weakly autobrecciated flow margins. The lavas enclose limited lithic pyroclastics and a blanket of monomictic volcanic conglomerate.

The carbonaceous greenschists make up heterogeneous strata, the main part of which is chloritic slates lacking evidence for primary ejecta or intensely decomposed detritus, except for some greywackes and mafic lapilli tuffs. Porous carbonate-chlorite-talc rock representing palaeoweathering lies at the base, and the slates are rich in sericite in the lower part, where a few sericite-quartzite or coarse-grained quartzite interbeds are present. The amount of graphite increases upwards and varies in beds so that black slate is present as interbeds in the upper part. The dark dust can also be sideritic in places. The jaspery and sulphidic laminae, dolomite and calcitic limestone lenses, and the banded iron formations with sulphide slates at PorkonenPahtavaara (Paakkola 1971) are also enveloped by the carbonaceous chlorite slates.

The volcaniclastic conglomerate has accumulated in an irregular blanket (h. $50 \mathrm{~m}$ ) on the komatiitic basalt and the carbonaceous greenschists, whereas it occurs at Kummitsoiva in a 
prismatic? body (thickness $<0.3 \mathrm{~km}$ ) overlying the graphitic slates. The phenoclasts $(\varnothing<60 \mathrm{~cm})$ derive from amphibole rock, greenstone or amphibolite, jaspilite, chert, dolomite, calc-silicate rock and greywacke. The coarse ejecta are in the form of cored lapilli of amphibole-chlorite rock or spilitic greenstone. The green greywacky matrix is rich in hornblende or contains mainly chlorite, albite and quartz but passes into a chlorite-talc-amphibole assemblage together with increasing tuffaceous material.

The pyroxene peridotitic komatiite, now represented by tremolite-chlorite rock, is pyroclastic and consists of lapillistone to tuff, with pyroclastic breccias and agglomerates being insignificant; reworked fabrics are not uncommon. Autobrecciated flows are block lavas or contain flow-top breccia, but the more massive lavas may be weakly vesicular and form a few lava pillows. The spinifex texture disappears, but relict phenocrysts of pyroxene and olivine are present in the basal cumulates and in dispersed crystal ejecta. Chlorite is a product after devitrificaton of glassy droplets and vitric ejecta.

The spilitic greenstone constitutes lava flows displaying flow and pillow structures, fragmentary features, cooling cracks and coarsely vesicular margins. The lavas are principally amphibole-albite rocks but sometimes epidote and chlorite are important minerals. The mineral assemblage in the most intensely spilitized rocks is albite-chlorite-epidote, albite-biotite or albiteparagonite. The rocks may also be carbonatized to various degrees. The amphibole is hornblende or actinolite, and the albite occurs as microlites, phenocrysts and varioles or ocelli. Several phaneritic greenstones of blastophitic texture and poor in plagioclase may be differentiates in the lava flows, but sills are also present as in the graphitic slate zone beneath the volcanic supercomplex. The lavas include tuffaceous intercalations in which the beds of jasper, jaspilite, graphite or dolomite make it difficult to distinguish the mafic tuffs from the carbonaceous greenschists, if indeed they really are distinct rocks. The spilitic greenstones are tholeiitic basalt and alkali-basalt in chemical composition (Sarapää 1980).

\section{Kumpu conglomerate-metasandstone-slate suite}

The Kumpu association is preserved in erosional remnants of depressional or synclinal deposits (thickness $0.8-2.7 \mathrm{~km}$ ) in which the basal greywacky conglomerates form wedge-shaped sheets (thickness < 0.3 km) (Haimi 1977; Räsänen 1977; Manninen 1981). The rocks apparently clastic are traced in following stratigraphic order.

The greywacky conglomerate is stratified in thick and thin phenoclast-supported beds with upward-fining interbeds of pebbly greywacke. The highly rounded clasts consist of greenstone, graphitic metasediments, amphibolite, carbonate rock, jaspilite, chert, albite diabase, felsic rock, sericite quartzite, arkose quartzite, calc-silicate rock, greywacke, gabbro, granitoid, granite and conglomerate. Sorting is poor or absent except in one marginal deposit containing greenstone fragments within a green matrix rich in chlorite and amphibole, and conglomerate bed having quartz pebbles and fuchsitic matrix. Bedding is obscure except within the distinct greywacke interbeds which display large to small-scale crossbeds, graded bedding, scour-and-fill structures and depositional disconformities. The sandy detritus is volcaniclastic lithic wacke, passing into calclithic as the amounts of carbonate and sericite increase. The colour is greenish to brownish due to the prevailing hornblende, chlorite or biotite. Typical heavy minerals are magnetite, haematite and tourmaline. Sericitic or dolomitic interbeds are rare.

The arkosic conglomerate (thickness $<0.2 \mathrm{~km}$ ) is pile of thick gravel beds and interbedded with and passing upwards into arkose quartzite. The phenoclasts $(\varnothing<40 \mathrm{~cm})$ are derived from quartzites (sericitic, arkosic, jaspery, quartzarenitic and fuchsitic), jaspilite, spilitic green- 
stone, slate, greywacke, graphitic metasediments, granitoid, gabbro and diabase. The sandy detritus is arkosic and the grains may be covered with haematite dust so that some of the lowermost interbeds of arkosic quartzite are brownish to red, as is characteristic of the Kumputunturi quartzite (Hackman 1927). A few cobbles of the Kumputunturi quartzite are found in the upper part of the deposit. Scour-and-fill structures and large-scale cross-beds are frequent.

The arkose quartzite is a coarse to fine-grained rock with sporadic pebbles of quartzites, quartz, slate and quartz-feldspathic rock. Alignments of pebbles indicate bedding in the otherwise massive rock. The clasts are quartz, K-feldspar and oligoclase-albite and the sericite-quartz matrix includes biotite in places.

The sericite quartzite is of quartz wacke or more rarely arkosic wacke, with the matrix being sericite, chlorite, quartz and carbonate. As matrix content increases, the rock passes into slate, and conversely, with decreasing matrix, becomes a quartz arenite. Quartzose laminae may accentuate $0.1-50 \mathrm{~cm}$ thick planar beds. Ripple marks, sometimes linguoid in shape, large-scale cross-beds mainly in planar sets, and mud cracks are frequent, whereas load cast and slump structures are less common. The highly to poorly rounded grains with or without secondary overgrowth are quartz (also chert), albite, K-feldspar and oligoclase. The most common heavy minerals are tourmaline, zircon and magnetite but there are occasionally enough haematite to tinge a brownish or red colour in particular as a dusty cover around the clasts. The sericite quartzite includes one or two thin greywacke interlayers with individual pebbles of quartz, quartzite and slate.

\section{Depositional evolution}

The numerous exposures of palaeoresidue developed in the Saamian quartz-feldspathic gneisses, along with basal arkoses, are pertinent indicators of a sialic continental environment in which the Lapponian supracrustal rocks are stratified.

The Lower Lapponian quartzite-schist sheet includes calc-silicate rock and dolomite, constituting a quartzite-carbonate-schist association that is typical of cratonic sedimentation (Pettijohn 1975, p. 573). The mud cracks and ripple marks imply a littoral environment, further indicated by the carbonatic sediments (see Veizer 1973) and the quartz-arenitic interlaminae, which may have accumulated under tidal conditions (Klein 1971, 1972) even though the more solid quartzose bodies argue rather for intense weathering combined with desert aeolian or surf action (Pettijohn et al. 1973, p. 227). However, the schist member shows typical structures of turbidity currents (Räsänen 1986), and highly decomposed debris has been transported as clay into semipelitic material in the depocentre.

The cratonic sedimentation was preceded by deep-seated fracturing in the sialic crust, accompanied by volcanism of the Möykkelmä komatiitic greenstones. The brittle crustal deformation may have speeded up at the end of the sedimentation stage, because numbers of block faults developed: the laterally extensive Salla greenstone complex is intruded by greenstone dykes, and the major felsic interlayer calls for swarms of eruption fissures to feed viscous magma into the large area. Smooth and coarsely vesicular flow structures, demonstrating subaerial eruptions (Macdonald 1972, ps. 68, 76), distinguish the greenstone complex although sporadic carbonaceous or carbonatic intercalations, rare lava pillows and sparse terrigenous accumulations are attributes of limited subaqueous conditions. In extent, framework and petrographic features the complex bear a strong resemblance to the plateau basalts described by Baragar (1977) and Williams and McBirney (1979, pp. 266-272), albeit lying greatly in a graben (Saverikko 1988a).

This volcanism was followed by a prominent period of erosion, that is evident in the LowerMiddle Lapponian marker bed; the widespread conglomeratic greywacke-slate blanket exhibits 
fabrics pertinent to debris flows grading into turbidity currents (Saverikko 1988a). Such sediment transport may have been connected with sharp uplift of the granitic basement blocks, to which conspicuous arkose accumulations such as the Orakoski arkose are usually related (Pettijohn et al. 1973, p. 184). Thin redbeds at the base represent a granite wash from remainder hills of the Saamian gneisses. The coarse-clastic deposit of the Orakoski arkose is characterized by channelfill cross-beds with channel-lag gravel (Saverikko 1988a), peculiar to alluvial fans of braided rivers (Reineck and Signh 1980, p. 302).

The thick uniform sheet of pelite with planar graded-bedded strata (Rask 1978; Saverikko 1988a) is strong evidence of turbidity currents in deeper water and of an unstable tectonic environment. Its compositional maturity, or aluminous clayey parentage (see Saverikko 1988a), is much like that of the palaeosoils upon mafic metavolcanic rocks (Reimer 1985). In this manner, the available amount of clayey debris may have been derived from the Salla greenstone complex of high relief.

The Sodankylä quartzite-slate association was deposited as arkosic sand into the composite bedsets like those found on flood plains (McKee et al. 1967), beach shelfes (Reineck and Signh 1980 , pp. 382-386) or in braided channel bars (Coleman 1969), and as silty to muddy debris in a tidal and/or storm-dominant environment (Nikula 1985; Saverikko 1988a). Hence, emergence before the stratification might be apparent.

Distinct eruptions of Fe-rich tholeiitic basalts preceded a depositional change to euxinicexhalative conditions which is accepted as the Middle-Upper Lapponian boundary. The graphitic slate zone forms a heterogeneous sequence like those in semi-obstructed depositional basins (Krumbein and Sloss 1963, p. 506). The effusive to explosive eruptions occurred in the basin bounded probably by fault scarps and volcanic barriers, discharging subordinate amounts of felsic to ultramafic material.

At the rifting margin of the continental basin
(Saverikko 1983; 1985; Manninen and Pihlaja 1988), the Kittilä greenstone supercomplex including the Sattasvaara komatiitic rocks, and the Sotkaselkä and Kummitsoiva komatiite complexes developed in Hawaiian to Strombolian eruptions with or without volcanic mud flows and weakly phreatic or phreatomagmatic features (Saverikko 1983, 1985). The subsidence was strong in the west (Paakkola 1971; Kallio 1980; Saverikko 1985), and at Kittilä, outside the key area, the jaspers surrounded by pillow lavas show primary features similar to those of submarine precipitates in geosynclinal basins (Kinnunen 1982). The vertical block movements caused convulsionary deposition (Mäkelä 1968) that is evidenced by sporadic extrabasinal quartzites within the carbonaceous greenschists, and volcaniclastic conglomerates.

Prior to deposition of the Kumpu conglomerate-metasandstone-slate suite, the Lapponian sequence was folded (Lehtonen et al. 1985a) and faulted, because the basal wedge-shaped greywacky conglomerate deposits appear to have levelled off depressional irregularities. The coarser clasts are locally well rounded, but the strata in general correspond in structure to talus fans (see Reineck and Signh 1980, pp. 302-303). The sericite-rich top of one deposit, which shows a zonal arrangement of chlorite and carbonate (Räsänen 1977), may signify palaeosoil development prior to deposition of the overlying gravelly arkosic sands.

The bulk of the Kumpu sediments are arkosic to quartzose sands with numerous polymictic gravel beds in the lower part. The mineralogical and textural maturity increases upwards suggesting advanced transgression together with enlargement of the source area over the margins of the Lapponian province, where quartzitic rocks prevail. The first sandy detritus intermingled with local gravel is represented by Kumputunturi quartzite, and some degree of lateritization in the provenance area is indicated (Mikkola 1941). The succeeding massive beds of arkose quartzite may imply a submarine fan (see Walker 1967, 1984) 
but the washout structures, ripple marks, mud cracks, large-scale cross-beds and quartzose interlaminae have developed in a littoral or coastal plain environment. Opposing palaeocurrentdirections (Räsänen 1977; Lehtonen et al. 1985a) may demonstrate local rifting at least at Kaarestunturi, northwest of Sodankylä.

\section{Regional geological setting}

The Lapponian sequence strikes across northern Finland from Sweden to the Soviet Union
(Fig. 5). The Middle Lapponian rocks form a widespread horizon beneath which the metavolcanic rocks corresponding to the Salla greenstone complex are known variously as the ?Upper Veikkavaara, the Siekkijoki, the Kaukonen greenstones and Greenstone I. The volcanic complexes are not always bimodal in composition, and mafic or felsic metavolcanic rocks prevail in places; graphitic or carbonate interlayers are present outside the key area as well. Beneath the greenstones the Lower Lapponian quartzitecarbonate-schist suite is known in Sweden as the Tjärrö quartzite (Witschard 1984), which

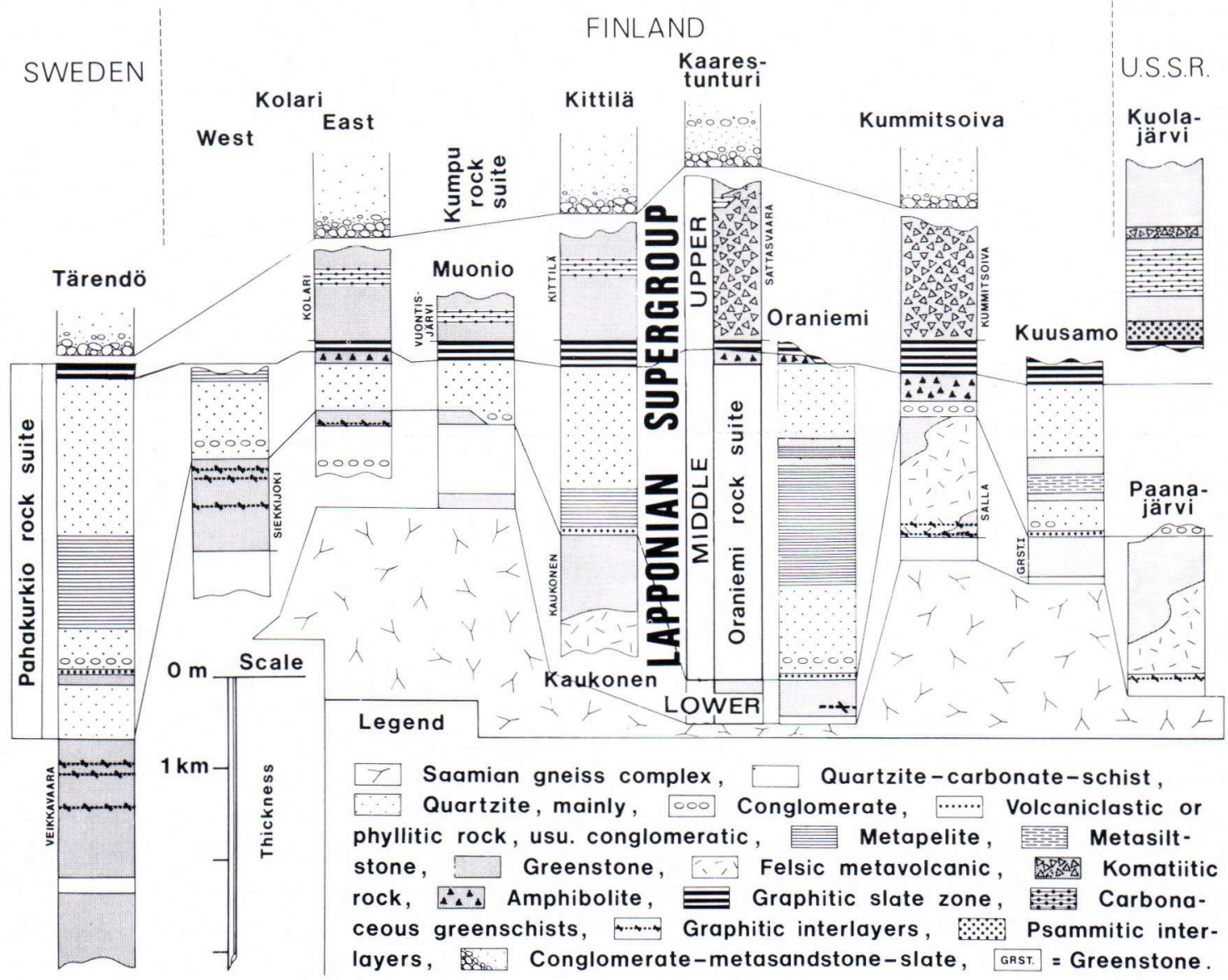

Fig. 5. The Lapponian supergroup is subdivided into Lower, Middle and Upper Lapponian groups from northwest to southeast. The stratigraphic records are drawn as follows: Tärendö (Padget 1970; Niiniskorpi 1986), Kolari (Hiltunen 1982), Muonio (Lehtonen 1984), Kittilä-Kaukonen (Rastas 1980, 1984), Kaarestunturi (Saverikko 1985), Oraniemi (Saverikko 1988a), Kummitsoiva (Saverikko 1980; Manninen 1981), Kuusamo (Silvennoinen 1972) and Kuolajärvi-Paanajärvi (Hackman and Wilkman 1929; Kulikov et al. 1980). 
is interstratified within the Veikkavaara greenstone complex (Padget 1970), indicating that the ?Lower Veikkavaara greenstones correlate with the Möykkelmä greenstones.

The Middle Lapponian group forms disjointed sedimentary deposits. The Oraniemi arkoseslate-quartzite association overlies the subsided Lappmark megablock (Saverikko 1988a) but it appears commonly as the Sodankylä quartzite in the west (Hackman 1927) until, in Sweden, it is found again as a distinct association in the $\mathrm{Pa}$ hakurkio rock suite (Fig. 6). The Pahakurkio succession is considered post-Lapponian (e.g. Witschard 1984), but the previous lithostratigraphic criteria may call for revision (Niiniskorpi 1986). A quartzite-greenstone-metasiltstone suite at Kuusamo in eastern Finland was laid down in the Kitka-Oulanka synclinal basin (Hackman and Wilkman 1929), where the sedimentary history (Silvennoinen 1972; Pekkala 1985) was comparable to that described earlier (Saverikko 1988a); however, Silvennoinen (1985) regards this suite as Jatulian. Isolated amphibolitic lava fields are also present elsewhere as in the key area (Latvalahti 1973; Hiltunen 1982).

In the Upper Lapponian the graphitic slate zone is irregularly covered by metavolcanic rocks and the Kittilä greenstone supercomplex known locally as the Kolari or Vuontisjärvi greenstones.

The Tuntsa-Savukoski high-grade metamorphic terrain is problematic in its stratigraphic relationship to both the Saamian and Lapponian provinces. Lithostratigraphic features suggest that the paragneiss suite, excluding the Tuntsa migmatite unit (Mikkola 1941; Joupperi 1983), forms part of the Lapponian supergroup (Fig. 7), and the fundamental unconformity dividing these paragneisses into two parts (Piirainen 1985) coincides well with the Lower-Middle Lapponian hiatus. Piirainen (1985) also considers the migmatite unit to be Lapponian, perhaps, because the Lapponian felsic metavolcanic rocks have undergone limited migmatization (Virransalo 1985), which is seen in an early stage at Jauratsi as well (Manninen 1981). At any rate, all the Saamian

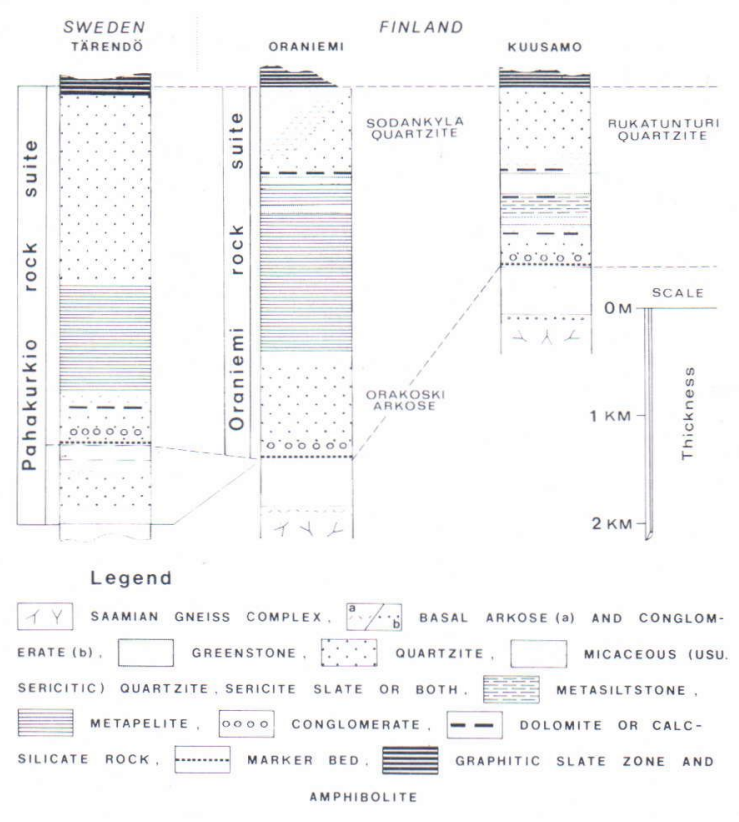

Fig. 6. Middle Lapponian type sections at Tärendö (Padget 1970; Niiniskorpi 1986), Oraniemi (Saverikko 1988a) and Kuusamo (Silvennoinen 1972).

paragneisses are here considered to be incorporated in the Tuntsan gneiss suite, in accordance with the current usage.

The granulite complex and the Lapland greenstone belt pass into each other despite the overthrust of the granulites upon the greenstones (Meriläinen 1976). The granulites have a bulk sedimentary parentage (Barbey et al. 1980, 1982, 1984; Hörmann et al. 1980) although metavolcanic rocks prevail in Soviet territory (Suslova 1976). The primary strata were a thick cyclic pile of arkosic and pelitic sediments with subordinate volcaniclastic greywackes, felsic volcanics, quartzites, graphitic and calc-silicatic sediments and tholeiitic basalts of massive or banded texture (Barbey et al. 1980, 1984); Suslova (1976) also reports pyroxene peridotitic komatiites in the Soviet Union. Orthogneisses or gneisses of unclear nature may derive from calc-alkaline basalts to rhyolites with abundant andesites (Barbey et al. 1980; Hörmann et al. 1980). The igneous rocks are chemically similar to those found in the 


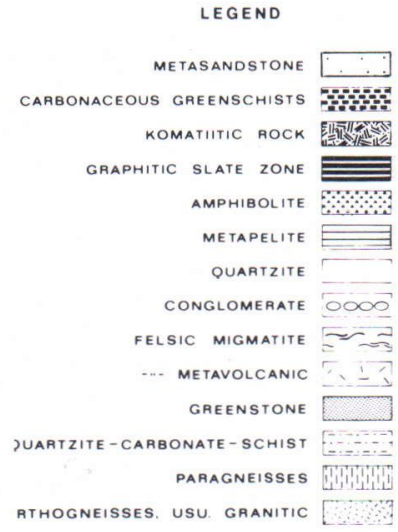

rig. 7. Lapponian rocks in the Tuntsa-Savukoski ultrametamorphic terrain. The stratigraphic columns at Kummitsoiva (Saverikko 1980, Manninen 1981), NE-Savukoski (Virransalo 1985) and Nuolusvaara (Veki 1985) are not excatly known to scale. Juopperi and Veki (1986) regard all the supracrustal rocks beneath the Nuolusvaara conglomerate as pre-Lapponian/ Tuntsan.

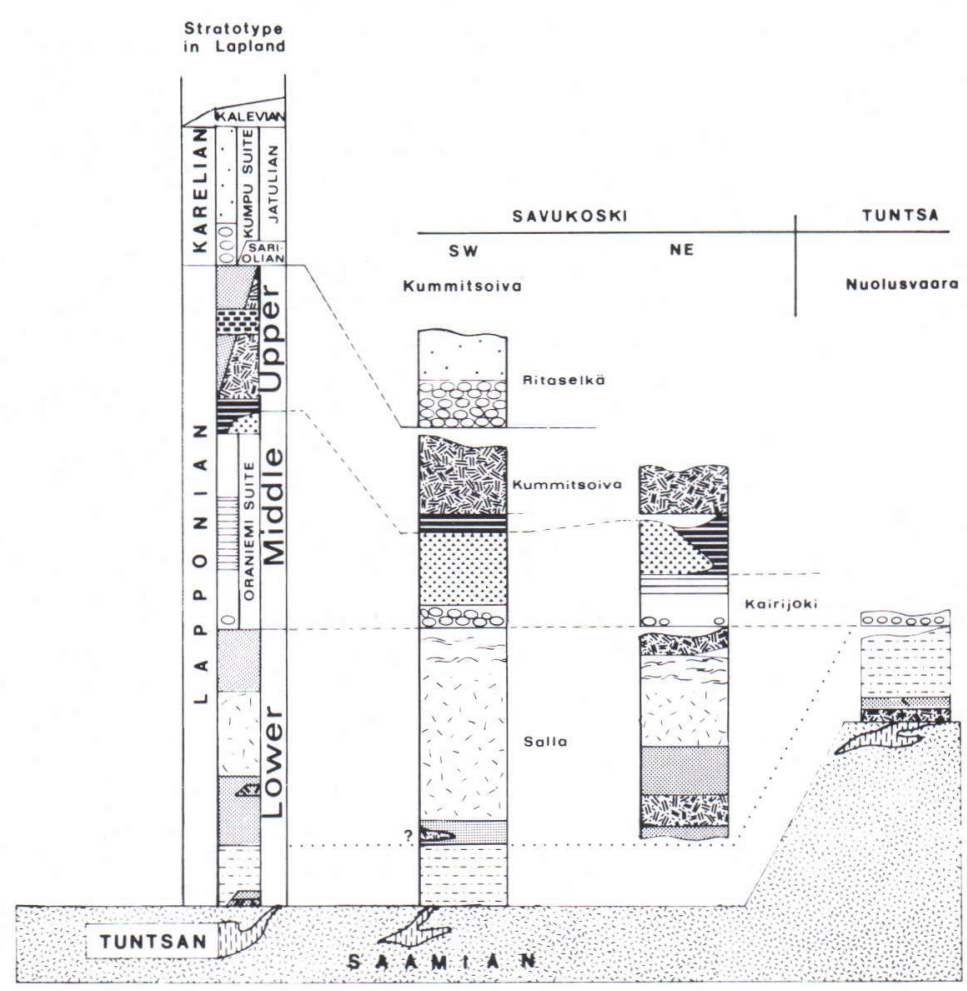

Archaean greenstone belts (Suslova 1976; Hörmann et al. 1980), and the sequence is in the parentage like the Lapponian. For example, the quartzofeldspar-g̀neiss-quartzite-mica-gneiss suite at the base (Meriläinen 1976) resembles the Lower Lapponian metasediments and, in the southwestern margin, it is accompanied by a bimodal metavolcanic complex showing signs of crustal contamination (Barbey et al. 1984). This volcanic-sedimentary gneiss assemblage underlies the khondalitic suite of arkosic and pelitic metasediments (Meriläinen 1976; Barbey et al. 1980) laid down in sediment gravity flow-dominated conditions (Barbey et al. 1984). Thick and cyclic sequence of khondalites may correspond to the Middle Lapponian metasediments, whereas the graphitic and calc-silicatic metasediments, felsic metavolcanic rocks and pyroxene peridotitic komatiites suggest an Upper Lapponian affinity. Further, Bernhard-Griffiths et al. (1984) estab- lish a Svecofennian age from a metavolcanic in the mafic charnockite suite.

The Karelian rocks, i.e. the Kumpu rock association, are at their most abundant in the west (Fig. 8). A few remnants are capped with the Svecofennian Latvajärvi felsic metavolcanics and Vesikkovaara conglomerate-metasandstonemetasiltstone suite (Rastas 1980). In practice the Kumpu rocks have been included in the Jatulian, but the basal greywacky conglomerates (Mäkelä 1968; Haimi 1977; Räsänen 1977; Rastas 1980; Kesola 1981; Manninen 1981) are petrographically quite unlike the overlying succession of polymictic conglomerate with arkosic groundmass and arkosic to quartzose metasandstones. In addition, they appear to be riftal in nature and to have undergone chemical weathering at the top, all signs pointing preferably to Sariolan characteristics (Meriläinen and Sokolov 1981; Marmo et al. 1986); neither are there any clear 


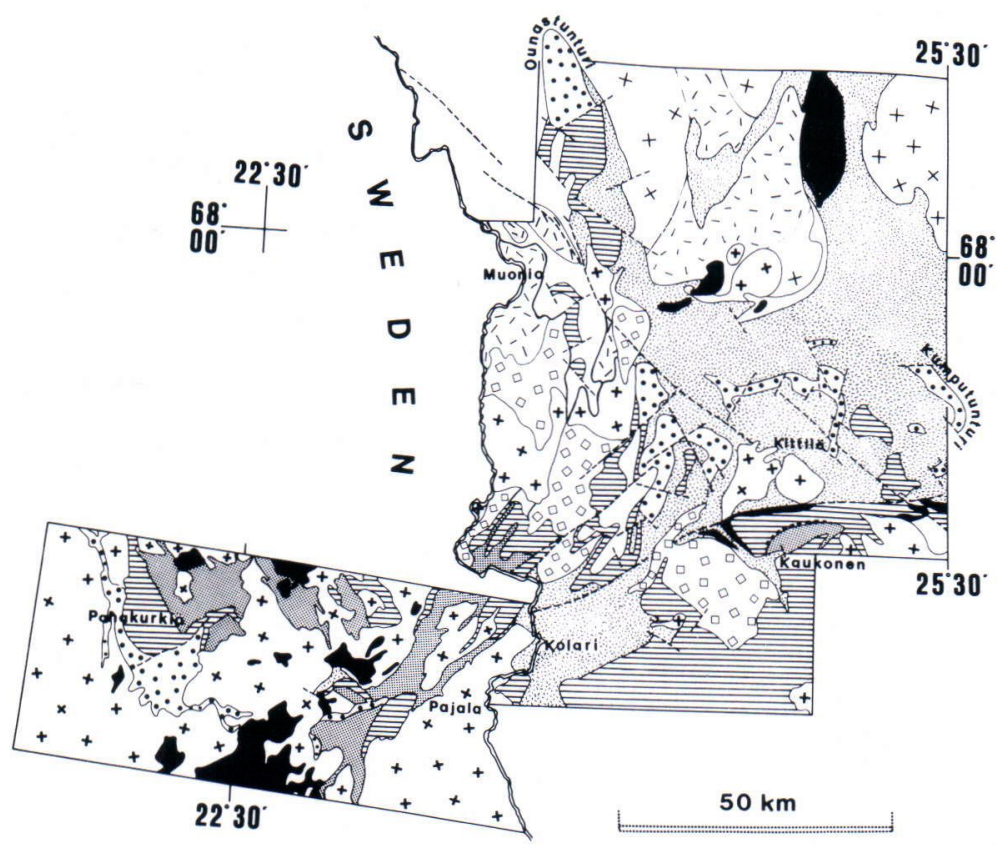

LITHOSTRATIGRAPHIC MAP

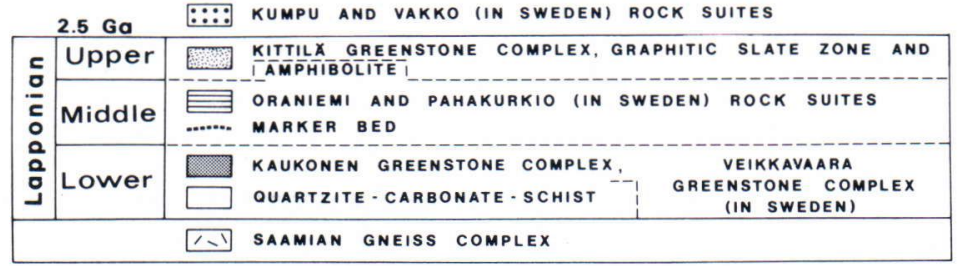

GABBRO,

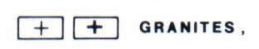

$+\square$ GRANITES
INFERRED FAULT.
Fig. 8. Geological sketch map of western Lapland, modified after Padget (1970, 1977), Silvennoinen et al. (1980), Hiltunen (1982) and Lehtonen et al. (1985a, b). The Sirkka conglomerate is tentatively separated from the Kumpu rock suite (see Figure 10). discrepancies between their ages (Fig. 9) and the Sariolan stage at $2.5-2.3 \mathrm{Ga}$.

The greywacky conglomerate has been arbitrarily connected with the Sirkka conglomerate, which is characterized by detritus derived from jaspilitic iron deposits and other Lapponian rocks (Hackman 1927; Mikkola 1941). But the volcaniclastic conglomerates (Saverikko 1980, 1983, 1985) or greywacky conglomerates of volcaniclastic origin (Mäkelä 1968; Kesola 1981; Kortelainen 1983), which are associated with the Upper Lapponian carbonaceous greenschists (Fig. 10), are petrographically similar to the Sirkka conglomerate. The latter has also been linked with the Kumpu rocks because of its position on a thin blanket of sericite quartzite, although analogous quartzitic portions are contained in the carbonaceous greenschists (Paakkola 1971; Latvalahti 1973; Räsänen 1977; Kesola 1981; Kortelainen 1983). Up to that, since the contact between the Sirkka conglomerate and the Kumpu rock suite proper is tectonic in nature (Mäkelä 1968; Ohlson 1969; Kortelainen 1983), the marginal conglomerates of the Kumpu deposits should not be correlated with the Sirkka conglomerate without more careful investigation! 


\section{Chronostratigraphic evaluation}

The granite-gneiss basement complex shows commonly datings of $2.8-2.6 \mathrm{Ga}$ (Simonen 1980), that is suggested by Silvennoinen (1985) as the age of cratonization. In the key area, however, the gneiss complex has been intruded by a tonalitic dome $3.1 \mathrm{Ga}$ old (Kröner et al. 1981) which belongs to the lithosphere developed during the Saamian diastrophism (Salop 1983, pp. $22-72$ ) and cratonized at $3.1-3.0 \mathrm{Ga}(\mathrm{Mu}-$ satov et al. 1984).

The lower time limit of the Lapponian is not precisely known but the mentioned age of $3.1 \mathrm{Ga}$ and that of $2.99 \mathrm{Ga}$ (Fig. 11) determined from a brecciated schist associated with ultramafic rocks (Papunen et al. 1977) may bracket the time interval within which the Lapponian started. The latter age is dated outside the key area and is considered less significant in this context because of the absence of stratigraphic information about the dated rock. Thus, the onset of the Lapponian appears to be related to the cratonization at $3.1-3.0 \mathrm{Ga}$, that is generally evidenced by the deposition of quartz arenites (Eriksson and Donaldson 1986) such as the Lower Lapponian quartzite. The oldest age, $2.79 \mathrm{Ga}$, with known stratigraphic position is from a felsic rock (Silvennoinen et al. 1980) of the Salla greenstone complex which also gives a disputable age of 2.4 Ga (M. Vaasjoki, pers. commun. 1986) for local basal conglomerate (Silvennoinen 1972) lying at a higher stratigraphic level than the felsic rock. The $2.4 \mathrm{Ga}$ age may indicate isotopic reset appropriate to emplacement of the nearby gabbro intrusions and thereby to the regional plutonic epoch at $2.45-2.43 \mathrm{Ga}$ in northern Finland (Simonen 1980).

The Möykkelmä greenstones at the base include komatiitic rocks, one of which is dated at 2.66 Ga. Räsänen (1984) regards this as a minimum age, a view that appears to be verified by an albite-rock dyke 2.72 Ga old, that intrudes at least the Lower Lapponian quartzite at Karasjok, in Norway (Meriläinen 1976). With
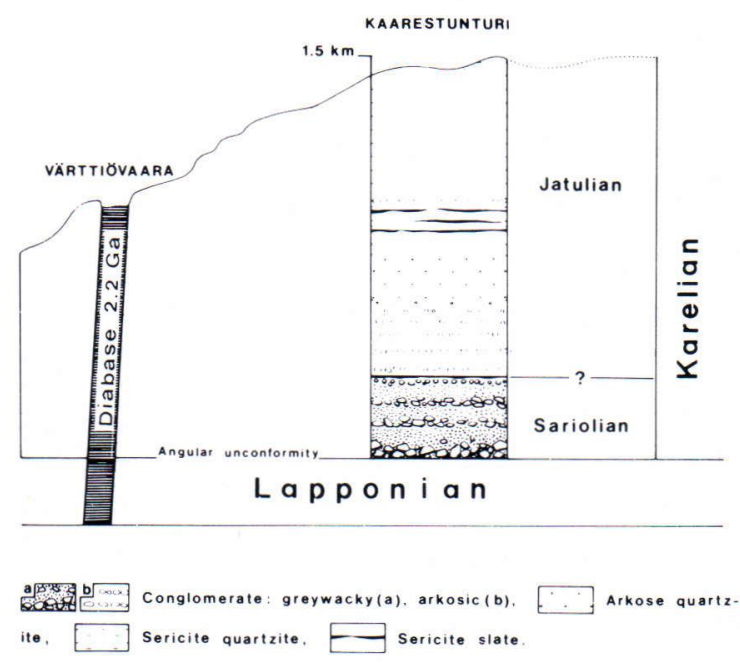

Fig. 9. Stratigraphic record of the Kumpu association at Kaarestunturi, northwest of Sodankylä (Räsänen 1977); the discordant diabases (Rastas 1980) are correlated after Nikula (1985).

or without connection with the dyke, two or more felsic metavolcanic rocks of $2.70 \mathrm{Ga}$ age (Rastas 1980; O.Kouvo, pers. commun. 1986) are included in the Upper Lapponian graphitic slate zone. Hence, a felsic rock of $2.53 \mathrm{Ga}$ age (Peltonen et al. 1986) may penetrate rather than be interstratified within the Lower-Middle Lapponian marker bed poorly unearthed.

The upper time limit of the Lapponian is also obscure, but the $2.44 \mathrm{Ga}$ Koitelainen gabbro laccolith (Puustinen 1977) is younger than the Upper Lapponian komatiites at Sattasvaara (see Saverikko 1985). The Kittilä greenstone supercomplex or its spilitic rocks have been considered early Proterozoic (e.g. Gaál 1986), mainly on the basis of diabases $2.20-1.95 \mathrm{Ga}$ old, but these diabases crosscut the complex and some of them intrude the Kumpu rock suite, too (Rastas 1980). Layered gabbro sills of similar age (Silvennoinen et al. 1980; Tyrväinen 1983) are sandwiched also within the Middle Lapponian strata, which have been intruded by a gabbro of $2.32 \mathrm{Ga}$ age (Manninen 1981). 


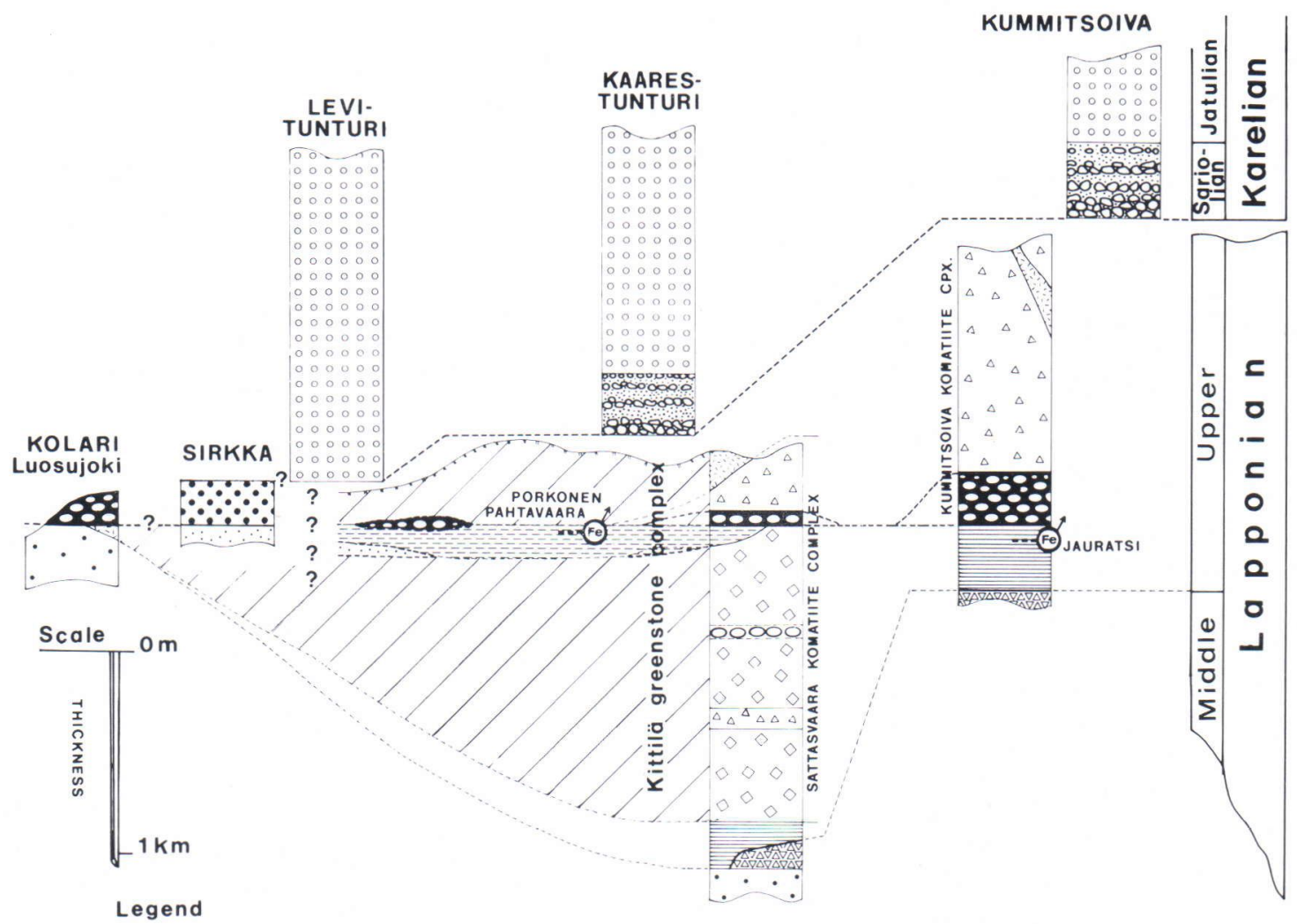

aboobseg Volcaniclastic conglomerate; monomictic(a), polymictic (b), $\because \because \because$ Sirkka conglomerate, Gaphitic slate zone,

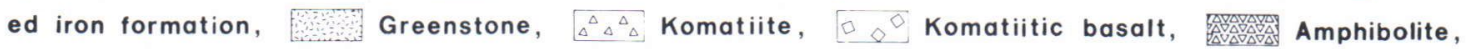

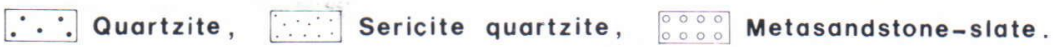

Fig. 10. Problematic stratigraphic position of the Sirkka conglomerate shown with respect to the Lapponian supergroup and Kumpu rock suite. The stratigraphic columns and principal references are: Kolari (Hiltunen 1982), Sirkka-Levitunturi (Kortelainen 1983), Kaarestunturi (Räsänen 1977), Sattasvaara (Saverikko 1985) and Kummitsoiva (Manninen 1981; Saverikko 1983).

In conclusion, the span of $3.0-2.5 \mathrm{Ga}$ is assumed for the Lapponian; the ages of Lower, Middle and Upper Lapponian cannot be resolved with the geochronological data available. The bulk of the Kumpu rock suite is older than 2.2 $\mathrm{Ga}$ and its minimum age may be $2.0 \mathrm{Ga}$, pointing to the Sariolan-Jatulian age. At Kittilä, it is capped with the Latvajärvi felsic metavolcanic rock, $1.89 \mathrm{Ga}$ old, and the Vesikkovaara conglomerate with granitic phenoclasts of 2.06$1.92 \mathrm{Ga}$ age (Rastas 1980).
As a chronostratigraphic enigma, the granulite complex is regarded as Archaean (2.8-2.5 Ga) by Meriläinen (1976) or as Karelian (2.4-2.0 Ga) by Barbey et al. (1984). Bernhard-Griffiths et al. (1984) have not recorded crustal events earlier than $2.0-1.9 \mathrm{Ga}$ ago but do not deny the possible existence of older events in the granulite complex. Ages of 2.0-1.9 Ga are found in the mafic charnockites of plutonic origin (Meriläinen 1976, Bernhard-Griffiths et al. 1984) which are emplaced between fault blocks (Meriläinen 


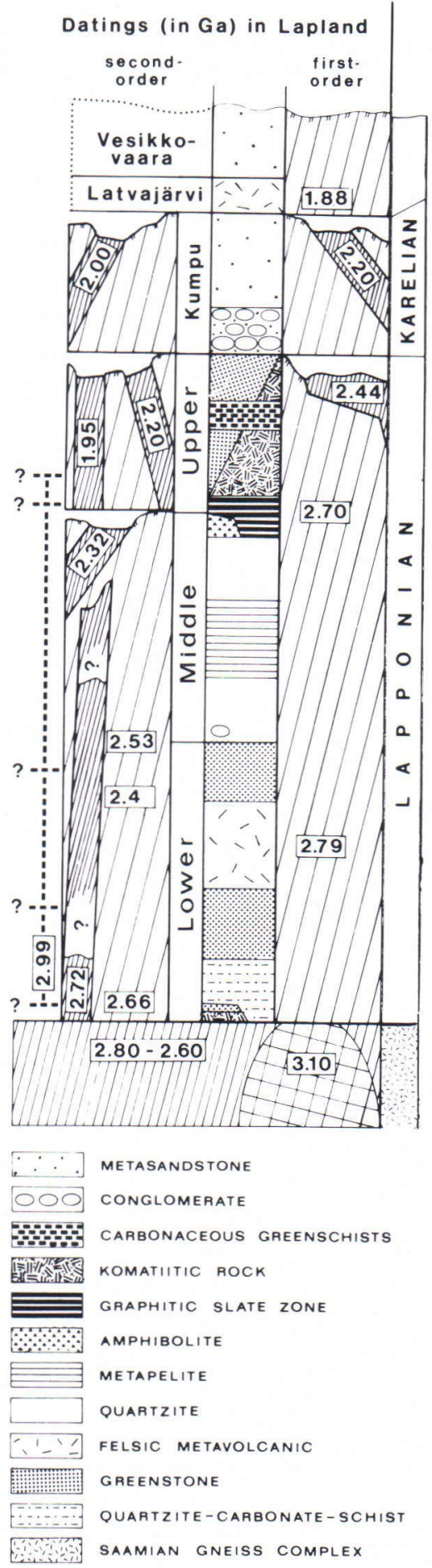

Fig. 11. Age determinations mentioned in the text and chronostratigraphic diagram of the Lapland greenstone belt.
1976) and hence show the minimum age of the sequence. The associated tectono-metamorphic convulsion is geochronologically verifiable in the khondalitic metasediments (Bernhard-Griffiths et al. 1984). The thick khondalite suite overlies the cratonic volcanic-sedimentary gneiss assemblage of ?Lower Lapponian origin that is older than a granite body of $2.36 \mathrm{Ga}$ age (Meriläinen 1976). These Tana River gneisses contain anorthosite bodies $1.9 \mathrm{Ga}$ old and a coeval metavolcanic rock (Bernhard-Griffiths et al. 1984) along the major thrust plane of the granulite arc (Barbey et al. 1984). Their tectonic situation appears to indicate concentration of magmatic activity in the reactivated marginal fault set of the depositional palaeobasion: as such, the geochronological knowledge available cannot be used to substantiate the original age of the granulite arc protoliths.

\section{Discussion}

The Saamian sialic crust including the Tuntsan terrigenous paragneisses developed before the Lapponian volcanic-sedimentary evolution 3.0$2.5 \mathrm{Ga}$ ago. Cratonization at $3.1-3.0 \mathrm{Ga}$ was apt for the deposition of the Lower Lapponian cratonic quartzite-carbonate-schist suite and the Salla greenstone complex of stable platformal volcanism. The Salla bimodal metavolcanic rocks and separated bodies of the Oraniemi arkose - slate-quartzite suite of Middle Lapponian constitute a bimodal-volcanic-quartzitearkose association which is indicative of cratonic rifting (Condie 1982, p. 232); the development of thin redbeds was feasible because of a sufficiently oxygenic atmosphere already in the Archaean (Windley and Simpson 1984). Tectonic stability implied by the euxinic-exhalative strata distinguishes cratonic rifting from plainly mantleactivated riftal processes (see Condie 1982, pp. 175-177) in which the Upper Lapponian komatiite-dominant volcanic piles discharged at distinct eruption centres in subaqueous-subaerial conditions. 
The nearly $5 \mathrm{~km}$ thick Lapponian sequence (see also Lanne 1979) indicates the magnitude of subsidence in Archaean depositional basins, depending on the lithospheric properties prevailing at that time (McKenzie et al. 1980). In contrast, the sequence, in which the komatiites are most dominant in the upper part, and the metasediments are more abundant in the lower and middle parts, shows the reverse stratigraphic order to that in the classic Archaean greenstone belt (Anhaeusser 1971). At any rate, the Upper Lapponian metasediments form a volcaniclastic greywackeargillite association which was typical of the Archaean, when coarse-clastic sediments in turn were rare (Lowe 1982), although cratonic riftal metasediments 3.0-2.5 Ga old appear also in South Africa (Burke et al. 1985; Eriksson and Donaldson 1986).

Further information from the Salla bimodal volcanic complex and the Middle Lapponian sediments may manifest the genetic linkage between the Lapland greenstone belt and the granulite arc which is part of the bimodal-volcanic-arkosepelite association (Barbey et al. 1984). They pass transitionally into each other (Meriläinen 1976), while the granulitized supracrustal sequence in Soviet territory is also 3 to $5 \mathrm{~km}$ thick (Suslova 1976). The geochronological data available is not incompatible with an Archaean age for the granulites.

With respect to the plate tectonic paradigm, the southwesterly overthrust of the granulite arc has been regarded as an attractive candidate for continental collision suture (Barbey et al. 1984, Marker 1985). In fact, the only direct evidence is that for the earlier continental rifting (Barbey et al. 1984) and the Archaean continental crust (Huhma 1986) beneath the granulitized epicontinental sediments (Barbey and Martin 1987); also, the proof of subducted oceanic crust is lacking. Palaeomagnetic data does not support significant microplate motions (Pesonen and Neuvonen 1981) but the sialic crust may have been fragmented into megablocks (Fig. 12); the Archaean continental crust in general was a mo- saic of separate megablocks which moved relative to one another forming riftal tracts suitable for the development of greenstone belts (Kröner 1981; Katz 1985). Bylinski et al. (1977) explain the overthrust in question by anticlockwise rotation of the Kola megablock (Fig. 13) since Late Archaean. The granulitic metasediments may be the fill of an intracontinental trench as was thought already by Barbey et al. (1980). Other tectonic movements are as follows: the Lappmark megablock is subsided (Saverikko 1988a), and the White Sea megablock may be inclined in consequence of preferential subsidence in the southeastern part (Akudinov et al. 1972, Bylinski et al. 1977) while the northwestern part rose requiring that the aulacogens (Saverikko 1988b) are opened away from the centre of uplift.

It is noteworthy that Bylinski et al. (1977) describe a mantle plume or diapir (Fig. 13) in association with the Belomorian/White Sea high-grade metamorphic terrain which is linked to that at Tuntsa-Savukoski. The mantle upwelling may be traced in Finland by an ultramafic intrusive zone (Papunen and Idman 1982) and a conformable line of the Upper Lapponian pyroclastic komatiite centres (Saverikko et al. 1985); a gradational metamorphic temperature maximum (Hörmann et al. 1980) also confirms the inferred mantle hot-line. In this respect, the granulite arc appears to indicate a concordant palaeotectonic basin adjacent to the mantle upwelling.

The Archaean origin of the Lapponian is finally manifested by stratigraphic similarities to the Kuhmoan supergroup (Saverikko 1988b), in which the shallow-water metasediments separate the two volcanic supercomplexes (Piirainen 1985; Barbey and Martin 1987) formed in the continental to oceanic riftal troughs (Martin et al. 1984). Laajoki (1986b) suggests a possible Sariolan age for the Lapponian supergroup, but the basal greywacky conglomerates of the Kumpu association show Sariolan characteristics unless that of glacial drift (Mikkola 1941) despite the glaciation of continental dimension (Ojakangas 1985). 


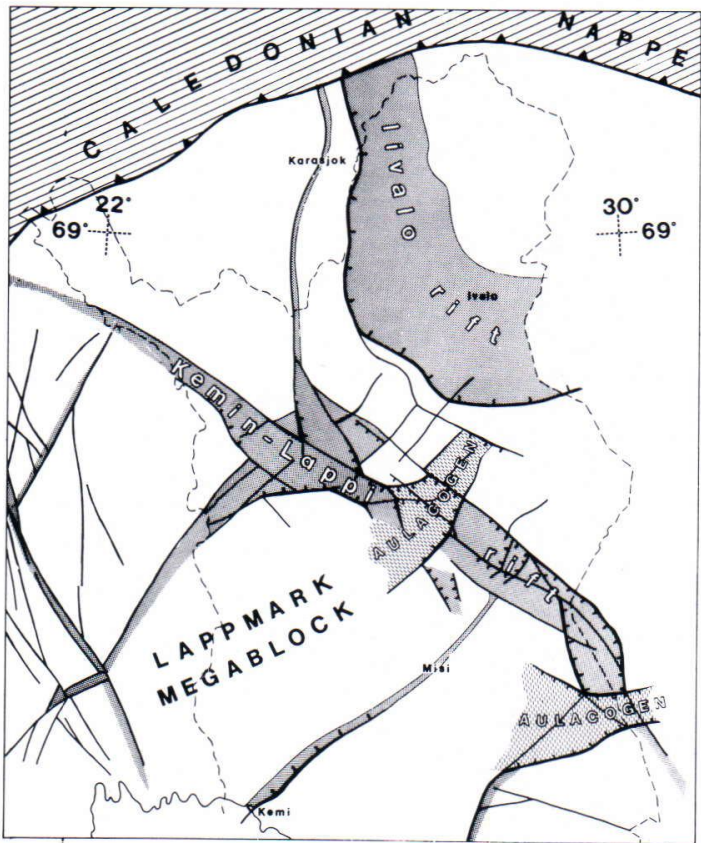

22

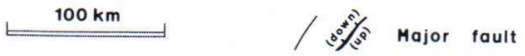

Rift, half-rift or inferred megablock boundary

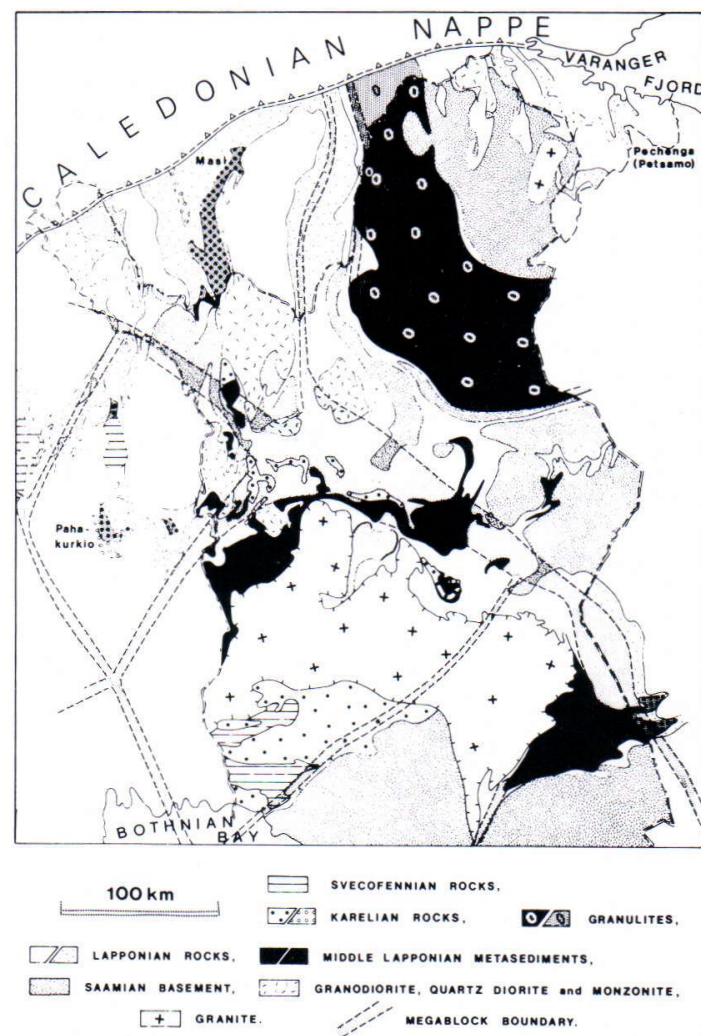

+ GRANITE

Fig. 12. Megablocks in northern Finland (see Saverikko 1988a). The distribution of the granulites relates more to the Middle Lapponian than to the Karelian metasediments.

The Lapland greenstone belt together with the granulitic belt resembles the Lopian greenstone belts, in adjacent U.S.S.R., which are similarly characterized by bimodal metavolcanic rocks (Musatov et al. 1984) and the flysch-like terrigenous metasediments at the middle level (Sokolov and Heiskanen 1985); the Lopian orogenic megacycle occurred between the Saamian and the Karelian, too (Kratz et al. 1984). Because the Lapponian and Kuhmoan provinces are part of the old-Scandinavian Cwenaland, it is here proposed that this greenstone-belt genesis should

Fig. 13. Proposed mantle diapir in the northern part of the Baltic/Fennoscandian Shield. Megablock boundaries are drawn after Bogdanov et al. (1973), Zhuravlev et al. (1980), Witschard (1984) and Saverikko (1988a).
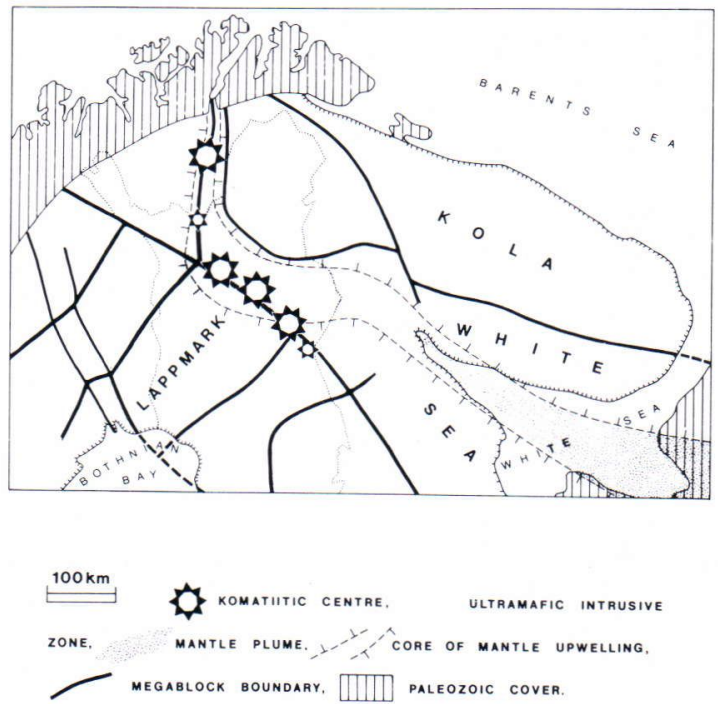
be called the Cwenan diastrophism or orogenic megacycle; the Lopian and Lapponian as words are ethnologic synonyms. Luukkonen and Lukkarinen (1986), on the other hand, associate the
Kuhmoan with the Samian and hence understand the Saamian system contrary to general opinion (Van Eysinga 1975; Salop 1983, p. 14).

\section{References}

Anhaeusser, C. R., 1971. Cyclic volcanism and sedimentation in the evolutionary development of the Archaean greenstone belts of shield areas. Geol. Soc. Aust., Spec. Publ. 3, 57-70.

Akudinov, S. A.; Bolgurtsev, N. N.; Litvinenko, I. V. \& Porotova, G. A., 1972. Deep structure of the eastern part of the Karelian region (from joint geophysical studies of the Lake Onega-White Sea profile). Geotectonics 5, 296-297.

Baragar, W. R. A., 1977. Volcanism of the stable crust. In: Baragar, W. R. A., Coleman, L. C. \& Hall, J. M. (eds.) Volcanic Regimes in Canada. Geol. Soc. Ass. Can., Spec. Paper 16, 377-405.

Barbey, P.; Convert, N. J.; Martin, H.; Moreau, B.; Capdevila, R. \& Hameurt, J., 1980. Relationships between granite-gneiss terrains, greenstone belts and granulite belts in the Archaean crust of Lapland (Fennoscandia). Geol. Rundsch. 69, 648-658.

-, Capdevila, R. \& Hameurt, J., 1982. Major and transition trace element abundances in the khondalite suite of the granulite belt of Lapland (Fennoscandia): Evidence for an Early Proterozoic flysch belt. Precambrian Res. 16, 273-290.

-, Convert, J.; Moreau, B.; Capdevila, R. \& Hameurt, J., 1984. Petrogenesis and evolution of an early Proterozoic collisional orogenic belt: The granulite belt of Lapland and the Belomorides (Fennoscandia). Bull. Geol. Soc. Finland $56,161-188$.

— \& Martin, H., 1987. The role of komatiites in plate tectonics. Evidence from the Archaean and early Proterozoic crust in the eastern Baltic Shield. Precambrian Res. 35, $1-14$.

Bernhard-Griffiths, J.; Peucat, J. J.; Postaire, B.; Vidal, Ph.; Convert, J. \& Moreau, B., 1984. Isotopic data (U-Pb, $\mathrm{Rb}-\mathrm{Sr}, \mathrm{Pb}-\mathrm{Pb}$ and $\mathrm{Sm}-\mathrm{Nd}$ ) on mafic granulites from Finnish Lapland. Preacambrian Res. 23, 325-348.

Bogdanov A. A.; Mouratov, M. V.; Khaine, V. E.; Koltchanov, V. P.; Leonov Y. G. \& Tchernook, S. V., (Compilers) 1973. International Tectonic Map of Europe and Adjacent Areas. $1: 2500$ 000. Unesco, Paris.

Burke, K.; Kidd, W. S. F. \& Kusky, T. M., 1985. The Pongola structure of southeastern Africa: the world's oldest preserved rift? J. Geodyn. 2, 35-49.

Bylinski, R; Glebovitski, V.; Dolivo-Dobrovvolski, A. \&

Porotova, G., 1977. The major Belomorian deep-fault zone. In: Kortman, C. (ed.) Fault Tectonics in the Eastern Part of the Baltic Shield. Proceedings of a FinnishSoviet Symposium, 20th-24th September, 1976, Finland. pp. $49-62$.

Coleman, J. M., 1969. Brahmaputra River: Channel processes and sedimentation. Sediment. Geol. 3, 129-239.

Condie, K. C., 1982. Plate Tectonics and Crustal Evolution. 2nd Edition. Pergamon Press, New York.

Eriksson, K. A.\& Donaldson, J. A., 1986. Basinal and shelf sedimentation in relation to the Archaean-Proterozoic boundary. Precambrian Res. 33, 103-121.

Eysinga, F. W. B. van (ed.), 1975. Geological Time Table. 3rd Edition. Elsevier, Amsterdam.

Fisher, R. V. \& Schmincke, H.-U., 1984. Pyroclastic Rocks. Springer-Verlag, Berlin, Heidelberg, New York, Tokyo.

Gaál, G., 1980. Geological setting and intrusion tectonics of the Kotalahti nickel-copper deposit, Finland. Bull. Geol. Soc. Finland 52, 101-128.

—, 1986. 2200 million years of crustal evolution: The Baltic Shield. Bull. Geol. Soc. Finland 58, 149-168.

— \& Gorbatschev, R., 1987. An outline of the Precambrian evolution of the Baltic Shield. Precambrian Res. 35, $15-52$.

—; Mikkola, A. \& Söderholm, B., 1978. Evolution of the Archean crust in Finland. Precambrian Res. 6, 199-215.

Hackman, V., 1927. Studien über den Gesteinsaufbau der Kittilä-Lappmark. Bull. Comm. Geol. Finlande 79.

—\& Wilkman, W. W., 1929. Suomen geologinen yleiskartta. Lehti-D6-Kuolajärvi. Kivilajikartan selitys. Geol. Surv. Finland, Espoo.

Haimi, M., 1977. Luoston alueen geologia. Unpubl. M. Sci. Thesis, Dept. Geol. Univ. Helsinki.

Hiltunen, A., 1982. The Precambrian geology and skarn iron ores of the Rautuvaara area, northern Finland. Geol. Surv. Finland, Bull. 318.

Honkamo, M., 1985. On the Proterozoic metasedimentary rocks of the northern Pohjanmaa schist area, Finland. Geol. Surv. Finland, Bull. 331, 117-129.

Hörmann, P. K.; Raith, M.; Raase, P.; Ackermand, D. \& Seifert, F., 1980. The granulite complex of Finnish Lapland: Petrology and metamorphic conditions in the Ivalo-Inarijärvi area. Geol. Surv. Finland Bull. 308.

Huhma, H., 1986. Sm-Nd, U-Pb and $\mathrm{Pb}-\mathrm{Pb}$ istotopic evidence for the origin of the Early Proterozoic Svecokarelian crust in Finland. Geol. Surv. Finland Bull. 337. 
—, 1987. Provenance of Early Proterozoic and Archaean metasediments in Finland: A Sm-Nd isotopic study. Precambrian Res. 35, 127-143.

Isomaa, J., 1978. Lapin liuskemuodostuma Petkulan alueella Sodankylän pohjoispuolella. Unpubl. M.Sci. Thesis, Dept. Geol., Univ. Oulu.

Juopperi, H., 1983. Savukosken-Tuntsan alueen vulkaniiteista. Geologi 35, 40.

- \&Veki, A., 1986. On the Archean Tuntsa supergroup in the Nuolusvaara area, northeastern Finland. In: Lång, K. (ed.) Abstracts. 17e Nordiska Geologmötet, 12-15. 5. 1986 Helsinki, p. 66.

Kahma, A., 1978. The main sulphide-ore belt of Finland between Lake Ladoga and the Bothnian Bay. Bull. Geol. Soc. Finland 50, 39-44.

Kallio, M., 1980. Keski-Lapin liuskealue Itä-Kittilän ja LänsiSodankylän osalta. Osa II: Rakenne ja stratigrafia. Unpubl. M.Sci. Thesis, Dept. Geol. Univ. Oulu.

—; Kärkkäinen, N. \& Sarapää, O., 1980. Keski-Lapin liuskealue Itä-Kittilän ja Länsi-Sodankylän osalta, osa I: petrografinen kuvaus ja kallioperä kartta. Unpubl. Research Report, Dept. Geol., Univ. Oulu.

Katz, M. B., 1985. The tectonics of Precambrian craton mobile belts: Progressive deformation of polygonal miniplates. Precambrian Res. 27, 307-319.

Kerkkonen, O., 1982. Raportti Jauratsin alueen kairauksista. Unpubl. Research report 030/3644/OK/82, Lapin Malmi, Rovaniemi.

Kesola, R., 1981. Kittilän Linkujoen vihreäkivien petrologiasta. Unpubl. M.Sci. Thesis, Dept. Geol. Univ. Helsinki.

Kinnunen, K., 1982. Primary sedimentary features in Kittilä jasper, Finnish Lapland. Bull. Geol. Soc. Finland 54, $69-76$.

Klein, G. deV., 1971. A Cambrian tidal sand body - the Eriboll Sandstone of Northwest Scotland, an ancientrecent analog. J. Geol. 79, 400-415.

—, 1972. Sedimentary model for determining paleotidal range, reply. Geol. Soc. Amer. Bull. 83, 539-546.

Kortelainen, V., 1983. Sirkka-konglomeraatin ja Levitunturin kvartsiitin sedimentologia Kittilässä. Unpubl. M.Sci. Thesis, Dept. Geol. Univ. Helsinki.

Kratz, K. O.; Bogdanov, Yu. B.; Zagorodnyi, V. G.; Negrutsa, V.Z.; Robonen, V. I. \& Sokolov, V. A., 1984. Type section of the Baltic Shield lower Precambrian. In: Bogdanov. N. A. (ed.) Abstracts II. 27th Int. Geol. Congress, 4th-14th August 1984, Moscow. 332-333.

Kröner, A., 1981. Precambrian plate tectonics. In: Kröner, A. (ed.) Precambrian Plate Tectonics. Elsevier Scientific Publishing Company, Amsterdam, pp. 57-90.

-; Puustinen, K. \& Hickman, M., 1981. Geochronology of an Archaean tonalitic gneiss dome in northern Finland and its relation with an unusual overlying volcanic conglomerate and komatiitic greenstone. Contrib. Mineral. Petrol. 76, 33-41.
Krumbein, W. C. \& Sloss, L. L., 1963. Stratigraphy and Sedimentation. 2nd Edition. W. H. Freeman and Company, San Francisco.

Kulikov. V. S.; Galdobina, L. P.; Voinov, A. S.; Golubev, A. I.; Kashpirov, S. I.; Polehovsky, Yu. S. \& Svetov, A. $P .$, 1980. Jatulian geology of the Paanajärvi-Kuolajärvi synclinorium. In Silvennoinen, A. (ed.) Jatulian Geology in the Eastern Part of the Baltic Shield. Proceedings of a Finnish-Soviet Symposium 21st-26th August, 1979, Finland. 73-96.

Laajoki, K., 1986a. The Central Puolanka Group - a Precambrian regressive metasedimentary sequence in northern Finland. Bull. Geol. Soc. Finland 58, 179-193.

-, 1986b. The Precambrian supracrustal rocks of Finland and their tectono-exogenic evolution. Precambrian Res. $33,67-86$.

Lanne, E., 1979. Vuotoksen ja Kittilän alueiden geofysikaalisten tietojen tulkinnasta. Summary: On the interpretation of geophysical data from the Vuotos and Kittilä areas, northern Finland. Geol. Surv. Finland, Rep. Invest. 25.

Latvalahti, U., 1973. Kittilän Pahtavuoman malmigeologiasta. Unpubl. M.Sci. Thesis, Dept. Geol., Univ. Turku.

Lauerma, R., 1982. On the ages of some granitoid and schist complexes in northern Finland. Bull. Geol. Soc. Finland $54,85-100$.

Lehtonen, M., 1984. Muonion kartta-alueen kallioperä. Lehti-2723-Sheet 1:100 000. Summary: Pre-Quaternary rocks of the Muonio map-sheet area. Explanation to the maps of Pre-Quaternary rocks. Geol. Surv. Finland, Espoo.

—; Manninen, T.; Rastas, P.; Väänänen, J.; Roos, S. \& Pelkonen, R., 1985a. Keski-Lapin geologisen kartan selitys. Summary and discussion: Explanation to the geological map of central Lapland. Geol. Surv. Finland, Rep. Invest. 71 .

—; Rastas, P. \& Väänänen, J., 1985b. Stratigraphic Map of Western Lapland, Northern Finland, 1:200 000. Geol. Surv. Finland, Espoo.

Leppänen, T., 1985. Savukosken Kiurujärven alueen kallioperän rakenne ja metamorfoosi. Unpubl. M.Sci. Thesis, Dept. Geol., Univ. Oulu.

Lowe, D. R., 1982. Comparative sedimentology of the principal volcanic sequences of Archean greenstone belts in South Africa, western Australia and Canada: Implications for crustal evolution. Precambrian Res. 17, 1-29.

Luukkonen, E., 1985. Structural and U-Pb isotopic study of late Archaean migmatitic gneisses of the Presvecokarelides, Lylyvaara, eastern Finland. Trans. R. Soc. Edinburgh Earth Sci. 76, 401-410.

— \& Lukkarinen, H., 1986. Explanation to the stratigraphic map of Middle Finland. Geol. Surv. Finland, Rep. Invest. 74 .

Macdonald, G. A., 1972. Volcanoes. Prentice-Hall, Inc. Englewood Cliffs. New Jersey.

Mäkelä, K., 1968. Sirkka-muodostumasta ja stratigrafian 
yleispiirteistä Keski-Lapin liuskealueella. Unpubl. Licentiate Dissertation, Dept. Geol., Univ. Oulu.

Manninen, T., 1981. Savukosken Akanvaaran alueen geologiasta. Unpubl. M.Sci. Thesis, Dept. Geol., Univ. Oulu.

— \& Pihlaja, P., 1988. The Archean volcanic rocks of the Peurasuvanto area, northern Finland. Geol. Surv. Finland, Spec. Paper (in press).

Marker, M., 1985. Early Proterozoic (c. 2000-1900 Ma) crustal structure of the northeastern Baltic Shield: Tectonic division and tectogenesis. Nor. Geol. Unders., Bull. 403, 55-74.

Marmo, J. \& Ojakangas, R. W., 1984. Lower Proterozoic glaciogenic deposits, eastern Finland. Geol. Soc. Am., Bull. 95, 1055-1062.

—; Kohonen, J.; Sarapää, O. \& Äikäs, O., 1986. Karjalaisen suurryhmän sedimentologiasta Kolin-Kaltimon alueella. (Abstract). In Laajoki, K.; Paakkola, J. \& Gehör, S. (eds.) Suomen kallioperän sedimentologia. Res Terrae (Dept. Geol., Univ. Oulu), B, 9, 7-8.

Martin, H., 1987. Evolution in composition of granitic rocks controlled by time-dependent changes in Proterozoic processes: Examples from the Archaean of eastern Finland. Precambrian Res. 35, 257-276.

-; Auvray, B.; Blais, S.; Capdevila, R.; Hameurt, J.; Jahn, B. M.; Piquet, D.; Quérré, G. \& Vidal, Ph. 1984. Origin and geodynamic evolution of the Archean crust of eastern Finland. Bull. Geol. Soc. Finland 56, 135-160.

Mattila, H., 1974. Karelidit Savukosken Tanhuan alueella, Keski-Lapissa. Unpubl. M.Sci. Thesis, Dept. Geol., Univ. Oulu.

McKee, E. D.; Grosby, E. J. \& Berryhill, H. L., 1967. Flood deposits. Bijou Creek, Colorado, June 1965. Sediment. Petrol. 37, 829-851.

McKenzie, D.; Nisbet, E. \& Sclater, J. G., 1980. Sedimentary basin development in the Archaean. Earth Planet. Sci. Lett. 48, 35-41.

Meriläinen, K., 1976. The granulite complex and adjacent rocks in Lapland, northern Finland. Geol. Surv. Finland, Bull. 281.

-, 1980. On the stratigraphy of the Karelian formations. In Silvennoinen, A. (ed.) Jatulian Geology in the Eastern Part of the Baltic Shield. Proceedings of a Finnish-Soviet Symposium 21st-26th August, 1979, Finland, pp. 97-112.

—\& Sokolov, V. A., 1981. Some attainments and problems relating to the geology of the Jatulian formations in Finland and Soviet Karelia. In Puustinen, K. (ed.) Geological, Geochemical and Geophysical Investigations in the Eastern Part of the Baltic Shield. 10th General Meeting of the Finnish-Soviet Joint Geological Working Group, 7th-11th September 1981, Rovaniemi. pp. 9-18.

Mikkola, E., 1941. Suomen geologinen yleiskartta. Kivilajikartan selitys. Lehdet-Sheets-B7-C7-D7: MuonioSodankylä-Tuntsajoki. General geological map of Finland. Summary: Explanation to the map of rocks. Geol. Surv. Finland, Espoo.
Musatov, D. I.; Fedorovsky, V. S.; Afanasyev, Yu. T. A.; Zonenshain, L. P.; Klenshch, K. A.; Kovalev, A. A.; Mezhelovsky, N. V.\& Sorokhtin, O. G., 1984. Some aspects of geology and geological history of the USSR territory according to new geotectonic concepts. In Volkov, V. M.; Eremeev, A. N.; Kireev, A. S.; Krasny, L. I.; Kulikov, G. V.; Mezhelovsky, N. V. \& Pushcharovsky, Yu. M. (eds.) Geology of the USSR. 27th Int. Geol. Congress, Moscow 4th-14th August, 1984. pp. 129-145.

Niemelä, M., 1976. Pelkosenniemen alumiini-rikkaat kiillegneissit. Unpubl. M.Sci. Thesis, Dept. Geol., Univ. Turku.

Niiniskorpi, V., 1986. Kurkkiovaara, en Zn-Pb-Cu mineralisering in norra Sverige, en case-studie. Unpubl. Licentiate Dissertation, Dept. Geol. Mineral., Åbo Akademi, Turku.

Nikula, R., 1985. Sodankylän Virttiö- ja Värttiövaaran metasedimenttien paleosedimentaatioympäristöt. Unpubl. M.Sci. Thesis, Dept. Geol., Univ. Oulu.

Nurmi, P. A. \& Haapala, I., 1986. The Proterozoic granitoids of Finland: Granite types, metallogeny and relation to crustal evolution. Bull. Geol. Soc. Finland 58, $203-233$.

Ohlson, B., 1969. Bedrock and Quaternary deposits of the Loukinen basin in western Finnish Lapland. Fennia 90, 2.

Ojakangas, $R$. W., 1965. Petrography and sedimentation of the Precambrian Jatulian quartzites of Finland. Bull. Comm. Geol. Finlande 214.

-, 1985. Evidence for Early Proterozoic glaciation: The dropstone unit-diamictite association. Geol. Surv. Finland, Bull. 331, 51-72.

Paakkola, J., 1971. The volcanic complex and associated manganiferous iron formation of the Porkonen-Pahtavaara area in Finnish Lapland. Bull. Comm. Geol. Finlande 247.

Paavola, J., 1986. A communication on the U-Pb and K-Ar age relations of the Archaean basement in the Lapinlahti-Varpaisjärvi area, central Finland. Geol. Surv. Finland, Bull. 339, 7-15.

Padget, P., 1970. Beskrivning till berggrundskartbladen Tärendö NV, NO, SV, SO. Sver. Geol. Unders. Af, 5-8.

—, 1977. Beskrivning till berggrundskartbladen Pajala NV, NO, SV, SO. Sver. Geol. Unders. Af, 21-24.

Papunen, H.; Idman, H.; Ilvonen. E.; Neuvonen, K. J.; Pihlaja, P. \& Talvitie, J., 1977. Lapin ultramafiiteista. Summary: The ultramafics of Lapland. Geol. Surv. Finland, Rep. Invest. 23.

— \& Idman, H., 1982. Ultramafic rocks and related ore minerals of Lapland, northern Finland. In Amstutz, G. C., Goresy, A. El., Frenzel, G., Kluth, C., Moh, G., Wauschkuhn, A. \& Zimmerman, R. A. (eds.) Ore Genesis, the State of the Art. Springer-Verlag, Berlin, pp. 374-386.

Pekkala, Y., 1985. Petrography, geochemistry and mineralogy of the Precambrian metasedimentary carbonate rocks 
in North Kuusamo, Finland. Geol. Surv. Finland, Bull. 332.

Pekkarinen, L. J., 1979. The Karelian formations and their depositional basement in the Kiihtelysvaara-Värtsilä area, East Finland. Geol. Surv. Finland, Bull. 301.

Peltonen, P.; Manninen, T. \& Pihlaja, P., 1986. A late Archean volcanic conglomerate in Peurasuvanto, northern Finland. In: Lång, K. (ed.) Abstracts. 17e Nordiska Geologmötet, Helsinki 12-15. 5. 1986, p. 146.

Perttunen, V., 1985. On the Proterozoic stratigraphy and exogenic evolution of the Peräpohja area, Finland. Geol. Surv. Finland, Bull. 331, 131-141.

Pesonen, L. J. \& Neuvonen, K. J., 1981. Palaeomagnetism of the Baltic Shield - implications for Precambrian tectonics. In Kröner, A. (ed.) Precambrian Plate Tectonics. Developments in Precambrian Geology 4. Elsevier Scientific Publishing Company, Amsterdam, 623-648.

Pettijohn, E. J., 1975. Sedimentary Rocks. 3 rd Edition. Harper \& Row, Publishers. New York.

-; Potter, P. E. \& Siever, R., 1973. Sand and Sandstone. Springer-Verlag, New York.

Piirainen, T., 1975. The Svecokarelian orogenic cycle and related metallogenesis in Finland. Bull. Geol. Soc. Finland 47, 139-153.

—, (ed.) 1985. Arkeeisten alueiden malmiprojektin loppuraportti. Rep. Invest. 28, Dept. Geol., Univ. Oulu.

Pulkkinen, E.; Rahkola, P. \& Saverikko, M., 1983, Case study of a geochemical anomaly in a komatiite area in northern Finland. In Björklund, A. \& Koljonen, T. (eds.) Abstracts. 10th IGES-3rd SMGP, August 29 to September 2, 1983, Espoo/Helsinki. p. 64.

Puustinen, K., 1977. Exploration in the northeast region of the Koitelainen gabbro complex, Sodankylä, Finnish Lapland. In Davis, G.R. (ed.) Prospecting in Areas of Glaciated Terrain. Inst. Min. Met. London. pp. 6-13.

Räsänen, J., 1977. Kaarestunturi-muodostuma ja sen sijainti Keski-Lapin liuskejaksossa. Unpubl. M.Sci. Thesis, Dept. Geol. Univ. Helsinki.

-, 1983. Keski-Lapin komatiiteista. English summary. Geologi 35, 25-29.

- 1984. On the Archean and Proterozoic komatiites in the Savukoski area, NE-Finland. In Armands, G. \& Schager, S. (eds.) Abstracts. 16e Nordiska Geologiska Ventermötet, 9-13. Januari 1984, Stockholm, p. 189.

—, 1986. Vuojärven alueen metasedimenttien paleosedimentologia. (Abstract). In Laajoki, K.; Paakkola, J. \& Gehör, S. (eds.) Suomen kallioperän sedimentologia. Res Terrae (Dept. Geol. Univ. Oulu), B, 9, 21.

-; Hanski, E. \& Lehtonen, M., 1986. Komatiites and tholeiites in the Möykkelmä area, northern Finland. In Lång, K. (ed.) Abstracts. 17e Nordiska Geologmötet, Helsinki 12-15. 5. 1986. p. 167.

Rask, M., 1978. Kivilajeista ja metapeliittien progressiivisesta metamorfoosista Sodankylän Kelujärven alueella. Unpubl. M.Sci. Thesis, Dept. Geol., Univ. Helsinki.
Rastas, P., 1980. Stratigraphy of the Kittilä area. In Silvennoinen, A. (ed.) Jatulian Geology in the Eastern Part of the Baltic Shield. Proceedings of a Finnish-Soviet Symposium, 21st-26th August 1979, Finland, pp. 145-152.

—, 1984. Geological Map of Finland. Pre-Quaternary Rocks. Sheet-2732-Kittilä, 1:100 000. Geol. Surv. Finland, Espoo.

Reimer, Th.O., 1985. Volcanic rocks and weathering in the Early Proterozoic Witwatersrand Supergroup, South Africa. Geol. Surv. Finland, Bull. 331, 33-49.

Reineck, H.-E. \& Singh, I. B., 1980. Depositional Sedimentary Environments. 2nd Edition. Springer-Verlag, Berlin.

Rieck, K.-H.; Borchert, H. \& Anger, G., 1967. Lagerstättenkundliche Untersuchungen am Eisenerzvorkommen Jauratsi in Finnisch Lapland. Bull. Comm. Geol. Finlande 226.

Salop, L. J., 1983. Geological Evolution of the Earth during the Precambrian. Springer-Verlag, Berlin.

Sarapää, O., 1980. Keski-Lapin liuskealue Itä-Kittilän ja Länsi-Sodankylän osalta, osa III: vulkaniittien geokemia. Unpubl. M.Sci. Thesis, Dept. Geol., Univ. Oulu.

Saverikko, M., 1978. Keski-Lapin liuskejakson stratigrafian, sedimentaation ja rakenteen pääpiirteet Sodankylän, Savukosken ja Pelkosenniemen alueella. Unpubl. Research Report 6/78, Lapin Malmi, Rovaniemi.

—, 1980. Keminniemen kallioperän stratigrafia, rakenteet, evoluutio ja malmikriittiset vyöhykkeet. Unpubl. Research Report 7/80, Lapin Malmi, Rovaniemi.

—, 1983. The Kummitsoiva komatiite complex and its satellites in northern Finland. Bull. Geol. Soc. Finland 55, $111-139$.

-, 1985. The pyroclastic komatiite complex at Sattasvaara in northern Finland. Bull. Geol. Soc. Finland 57, 55-87.

—, 1988a. The Oraniemi arkose-slate-quartzite association: An Archaean aulacogen fill in northern Finland. Geol. Surv. Finland, Spec. Paper, (in press).

—, 1988b. Arkeeinen laattatektoniikka-hypoteesi Fennoskandian Kilveltä. An Archaean plate-tectonic hypothesis in the Fennoscandian Shield; a preliminary note. Geologi 40, (in press).

— \& Manninen, T., 1981. Keminniemi/Saijan osa-alueen kivilajit, stratigrafia, rakenteet ja malmikriittiset vyöhykkeet. Unpubl. Research report 8/81, Lapin Malmi, Rovaniemi.

_; Koljonen, T. \& Hoffrén, V., 1985. Palaeogeography and palaeovolcanism of the Kummitsoiva komatiite complex in northern Finland. Geol. Surv. Finland, Bull. 331, $143-158$.

Sederholm, J. J., 1932. On the geology of Fennoscandia with special reference to the pre-Cambrian. Bull. Comm. Geol. Finlande 98.

Silvennoinen, A., 1972. On the stratigraphic and structural geology of the Rukatunturi area, northeastern Finland. Geol. Surv. Finland, Bull. 257. 
-, 1985. On the Proterozoic stratigraphy of northern Finland. Geol. Surv. Finland, Bull. 331, 107-116.

-; Honkamo, M.; Juopperi, H., Lehtonen, M.; Mielikäinen, P.; Perttunen, V.; Räsänen, J. \& Väänänen, J., 1980. Main features of the stratigraphy of North Finland. In Silvennoinen, A. (ed.) Jatulian Geology in the Eastern Part of the Baltic Shield. Proceedings of a Finnish-Soviet Symposium 21st-26th August, 1979, Finland. pp. $153-162$.

Simonen, A., 1971. Das finnische Grundgebirge. Geol. Rundsch. 60, 4, 1406-1421.

-, 1980. The Precambrian in Finland. Geol. Surv. Finland Bull. 304 .

—\& Kouvo, O., 1955. Sandstones in Finland. Bull. Comm. Geol. Finlande 168, 57-87.

Sokolov, V. A. \& Heiskanen, K. I., 1985. Evolution of Precambrian volcanogenic-sedimentary lithogenesis in the south-eastern part of the Baltic Shield. Geol. Surv. Finland, Bull. 331, 91-106.

Suslova, S. N., 1976. Komatiites in Lower Precambrian metavolcanic units of the Kola Peninsula. Dokl. Akad. Nauk. SSSR 228, 162-165.

Tyrväinen, A., 1983. Sodankylän ja Sattasen kartta-alueiden kallioperä. Lehdet-3713, 3714-Sheets, 1:100 000. Summary: Pre-Quaternary rocks of the Sodankylä and Sattanen map-sheet areas. Explanation to the maps of PreQuaternary rocks. Geol. Surv. Finland, Espoo.

Veizer, J., 1973. Sedimentation in geologic history: Recycling vs. evolution or recycling with evolution. Contrib. Mineral. Petrol. 38, 261-278.

Veki, A., 1985. Sallan Nuolusvaaran konglomeraatti sekä ympäristön kallioperän litostratigrafia ja rakenne. Unpubl. M.Sci. Thesis, Dept. Geol., Univ. Oulu.
Virransalo, P., 1985. Savukosken koillisosan kallioperän stratigrafia, rakenne ja metamorfoosi. Unpubl. M.Sci. Thesis, Dept. Geol., Univ. Oulu.

Walker, R. G., 1967. Turbidite sedimentary structures and their relationship to proximal and distal depositional environments. J. Sediment. Petrol. 37, 25-43.

-, 1984. Facies models 8 . Turbidites and associated coarse clastic deposits. In: Walker, R. G. (ed.) Facies Models. 2nd Revised Edition. Geosci. Can. Repr. Ser. 1, 171-188.

Ward, P., 1987. Early Proterozoic deposition and deformation at the Karelian craton margin in southeastern Finland. Precambrian Res. 35, 71-93.

Williams, H. \& McBirney, A. R., 1979. Volcanology. Freeman, Cooper \& Co., San Francisco.

Windley, B. F. \& Simpson, P. R., 1984. Geological evidence for an oxidising terrestrial atmosphere since the Early to Mid-Archaean and some implications for Precambrian metallogenesis. In Bogdanov, N. A. (ed.) Abstracts 2. 27th Int. Geol. Congress, 4th-14th August 1984, Moscow, p. 408.

Witschard, F., 1984. The geological and tectonic evolution of the Precambrian of northern Sweden - a case for basement reactivation? Precambrian Res. 23, 273-315.

Zhuravlev, V.; Ivanov, N.: Negrutza, V.\& Pushkin, G., 1980. Prejatulian formations of the link zone between Karelides and Belomorides. In: Silvennoinen, A. (ed.) Jatulian Geology in the Eastern Part of the Baltic Shield. Proceedings of a Finish-Soviet Symposium, 21st-26th August, 1979. $239-251$

Manuscript received August 21, 1986. 